\title{
Pacific Northwest Laboratory Report on Fusion Energy Research October 1976 - December 1976
}

January 1977

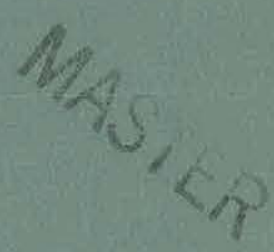

Prepared for the Energy Research and Development Administration under Contract EV-76-C-06-1830 


\section{DISCLAIMER}

This report was prepared as an account of work sponsored by an agency of the United States Government. Neither the United States Government nor any agency Thereof, nor any of their employees, makes any warranty, express or implied, or assumes any legal liability or responsibility for the accuracy, completeness, or usefulness of any information, apparatus, product, or process disclosed, or represents that its use would not infringe privately owned rights. Reference herein to any specific commercial product, process, or service by trade name, trademark, manufacturer, or otherwise does not necessarily constitute or imply its endorsement, recommendation, or favoring by the United States Government or any agency thereof. The views and opinions of authors expressed herein do not necessarily state or reflect those of the United States Government or any agency thereof. 


\section{DISCLAIMER}

Portions of this document may be illegible in electronic image products. Images are produced from the best available original document. 


\section{NOTICE}

This report was prepared as an account of work sponsored by the United States Covernment. Neither the United States nor the Energy Research and Development Administration, nor any of their employees, nor any of their contractors, subcontractors, or their employees, makes any warranty, express or implied, or assumes any legal liability or responsibility for the accuracy, completeness or usefulness of any information, apparatus. product or process disclosed, or represents that its use would not infringe privately owned rights.

PACIFIC NORTHWEST LABORAIURY

operated by

BATTELLE

for the

ENERGY RESEARCH AND DEVEIOPMENT ADMINISTRATION

Under Contract EY-76-C-06-7830

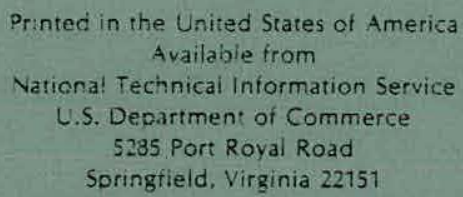

Price: Printed Copy 5

- Microfiche $\$ 3.00$

$\begin{array}{cc}\text {.Pages } & \text { NTIS } \\ 001-025 & \text { Selling Price } \\ 026-050 & \$ 4.50 \\ 051-075 & \$ 5.00 \\ 075-100 & \$ 5.50 \\ 107-125 & \$ 6.00 \\ 126-150 & \$ 6.50 \\ 15 !-175 & \$ 7.00 \\ 176-2000 & \$ 7.75 \\ 207-225 & \$ 8.50 \\ 225-250 & \$ 8.75 \\ 257-275 & \$ 9.00 \\ 276.300 & \$ 70.00 \\ & \$ 70.25\end{array}$


BNWL- 1939-6

UC-20

PACIF IC NORTHWEST LABORATORY

REPORT ON FUSION ENERGY RESEARCH

OCTOBER 1976 - DECEMBER 1976

January 1977

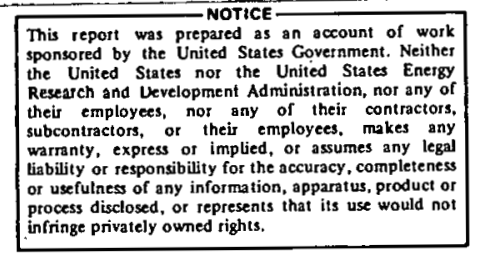

\section{BATTELLE}

Pacific Northwest Laboratories Richland, Washington 99352 

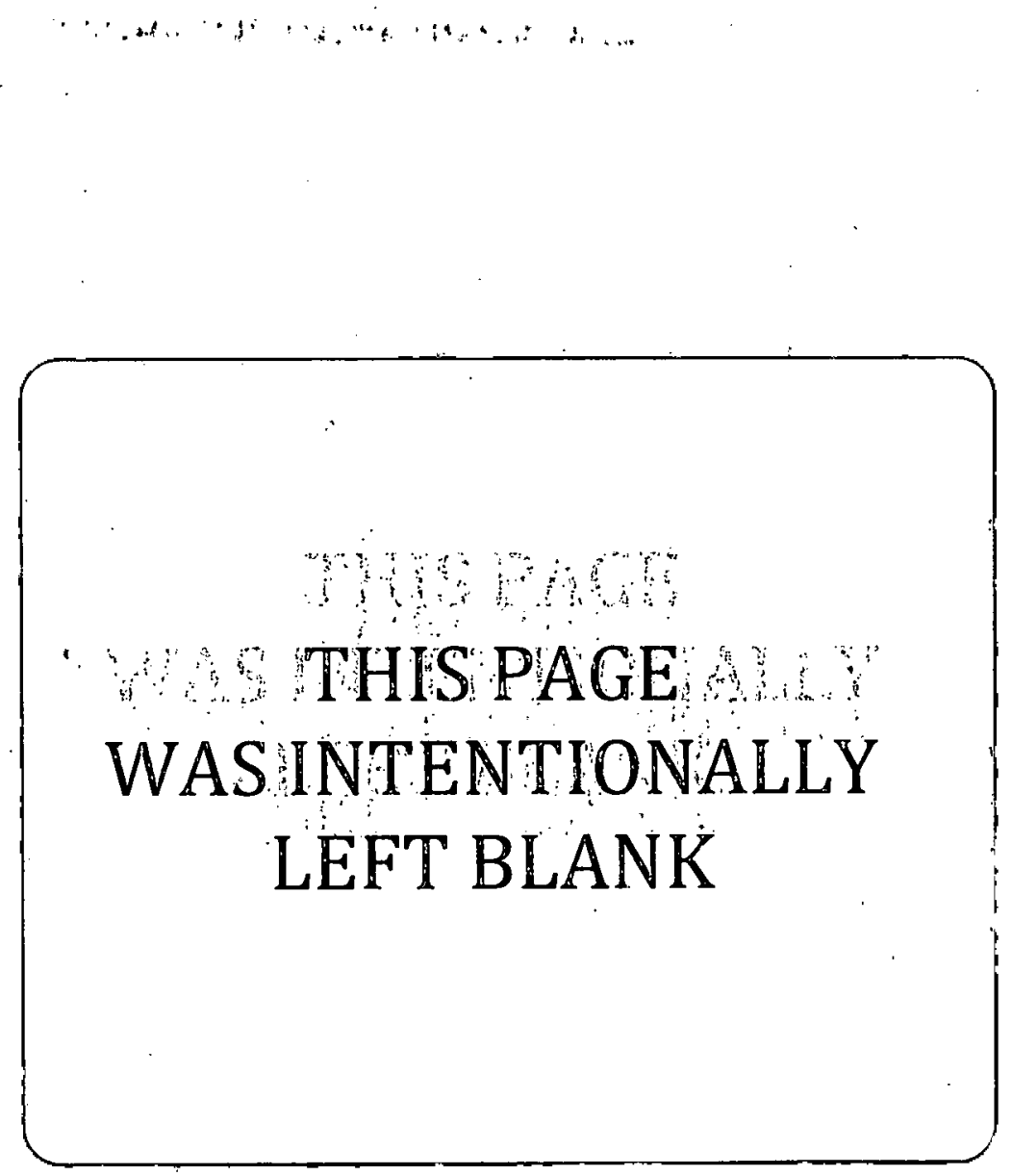


\section{PREFACE}

This quarterly report on Fusion Energy Research consists of progress summaries of research conducted by the staff of Pacific Northwest Laboratories (PNL). This reporting period includes progress made from October 1, 1976 through December 31, 1976. "The ERDA Division of Magnetic Fusion Energy is a major sponsor of the work. However, fusion-related work sponsored by others is also included as appropriate.

The summaries are presented in four major sections:

- Fusion Systems Engineering

- Materials Research and Radiation Environment Simulation

- Safety. Analysis and Environmental Effects of Fusion Concepts:

- Manpower Development

At the beginning of each section is a brief summary of the reports making up the section. The reports themselves have been kept relatively short and include preliminary results which ultimately are expected to be published elsewhere. Because of this, the reader is cautioned that the results may be modified before they are finalized. In some cases, reference is made to more complete reports that are available now.

D. A. Dingee

- Fusion Programs Manager

\section{Other Reports in the Series:}

Annual Controlled Thermonuclear Reactor Technology Report-1971, BNWL-1604.

Annual Report on Controlled Thermonuclear Reactor Technology-1972, BNWL-1685.

Annual Report for 1973 on Controlled Thermonuclear Reactor Technology, BNWL-1823.

Annual Report for 1974 on Controlled Thermonuclear Reactor Technology, BNWL-1890.

Report on Controlled Thermonuclear Reactor Technology, January through September 1975, BNWL-1939-1.

Report on Controlled Thermonuclear Reactor Technology, October through December 1975, BNWL-1939-2.

Report on Controlled Thermonuclear Reactor Technology, January through March 1976; BNWL-1939-3.

Report on Controlled Thermonuclear Reactor Technology, April through June 1976, BNWL-1939-4.

Report on Fusion Energy Research, July through September 1976, BNWL-1939-5. 


\section{CONTENTS}

LIST OF. FIGURES

LIST OF TABLES

SUMMARY

FUSION SYSTEMS ENGINEERING

SYSTEMS STUDIES

TETR-HYBRID SCOPING STUDY

V. L. Teofilo, R. T. Perry, B. R. Leonärd, Jr., M. A. Mckinnon

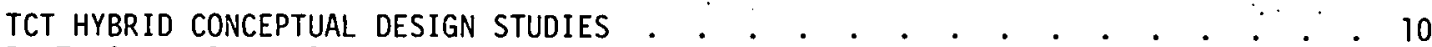

D. T. Aase, R. T. Perry, M. C. C. Bampton, R. A. McCann

HYBRID STUDIES - THE QUALITY OF FISSILE FUEL BRED IN A FUSION REACTOR BLANKET. $\because 12$

$B$. R. Leonard, Jr., U. P. Jenquin

PREL IMINARY ECONOMIC ANALYSIS

J. R. Young

ECONOMIC REGIMES .

D. E." Deonigi, R. L. Engel

BLANKET AND SHIELDING ENGINEERING

HEAT TRANSFER AND FLUID FLOW.

A. M. Sutey, D. T: Aase

NUCLEAR DATA STANDARDS

B. R. Leonard, Jr.

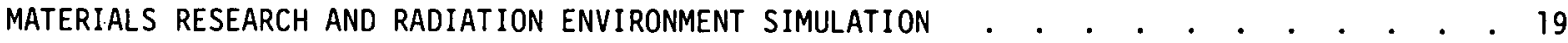

SURFACE SCIENCE RESEARCH: RELATED TO FUSION TECHNOLOGY . . . . . . . . . . . . . 21

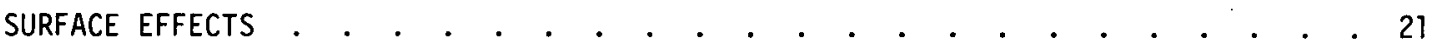

D. L. Styris, M. T. Thomas

BULK RADIATION EFFECTS AND SIMULATION

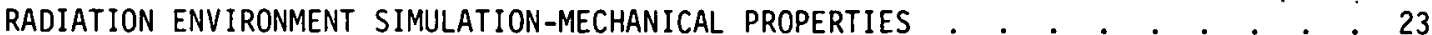

R. H. Jones, D. L. Styris

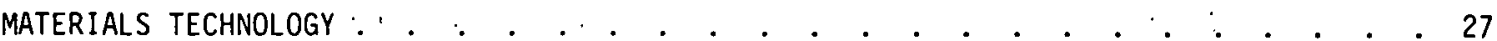

EVALUATION OF CARBONS AND GRAPHITES FOR

FUSION REACTOR APPLICATIONS

W. J. Gray, W. C. Morgan, G. L. Tingey

ELECTRICAL INSULATORS FOR FIISION REACTOR APPLICATIONS . . . . . . . . . 30

J. L. Bates, J. E. Garnier

SAFETY ANALYSIS AND ENVIRONMENTAL EFFECTS OF FUSION CONCEPTS . . . . . . . . . . . . . . 33

ENVIRONMENTAL EFFECTS ANALYSIS . . . . . . . . . . . . . . . . . . . . . . 35

FUSION REACTOR ENVIRONMENTAL EFFECTS . . . . . . . . . . . . . . . . . . .

J. R. Young

FUSION SYSTEM SAFETY ANALYSIS . . . . . . . . . . . . . . . . . . . 36

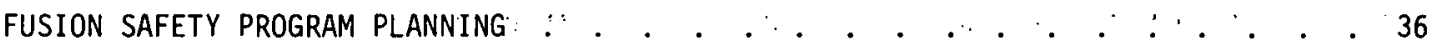

H. J. Willenberg, S. H. Bush

MANPOWER DEVELOPMENT . . . . . . . . . . . . . . . . . . . . . . . 37

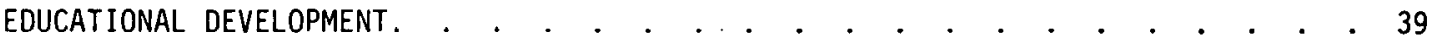

B. F. Gore, A. B. Johnson, Jr., $\dot{H}$. B. Liemohn, $\dot{F}$. $\dot{P}$. Hungate

REFERENCES

PUBLICATIONS AND PRESENTATIONS . . . . . . . . . . . . . . . . . . . . . . . . . . . . . . . 42

DISTRIBUTION .

.Distr-1 


\section{LIST OF FIGURES}

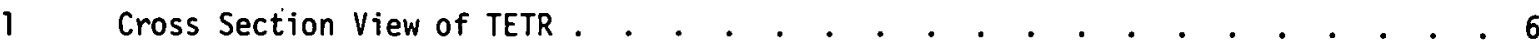

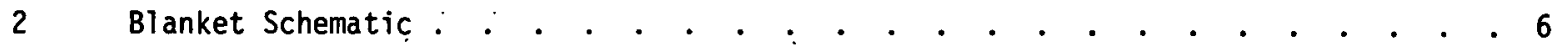

3 Vertical Cross Section of TETR Showing Hybrid Blanket Modular Layout . . . . . 7

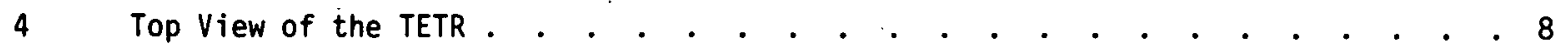

5 Cumulative Present Worth Cost of R\&D as a Function of Fusion Power Plant Availability Date. . . . . . . . . • • • . • • • • . . . . . 15

6 Calculated Present Worth Benefits for a Fusion Power Plant as a Function of Plant Availability Date. . . . . . . . . . . . . . . . . . . . 16

7 Comparison of soys Versus Neutron Fluence for Fusion and Fission Neutron-Irradiated Nickel, Copper, and 316 SS . . . . . . . . . . . . . . 24

8 Comparison of $\Delta \sigma y s$ for Niobium Wire (PNL) and Sheet (LLL) Irradiated with Fusion Neutrons at $20^{\circ} \mathrm{C}$. . . . . . . . . . . . . • . . . . 25

9 Carborundum Graphite Cloth, CSGC-2 . . . . . . . . . . . . . . . . 29

10 Thornel-50 Graphite Cloth . . . . . . . . . . . . . . . . . . . 29

11 Schematic Diagram of Degassing Apparatus . . . . . . . . . . . . . . . . 29

12. Circuit Schematic for Detection and Measurements of Acoustic Emissions and Discharge Pulses in Insulator Materials . . . . . . . . . . . . . . 32

\section{LIST OF TABLES}

$\mathrm{U0}_{2}$-Fueled TETR-Hybrid Blanket-Pu Production . . . . . . . . . . . . . . 8 Advanced Fueled TETR-Hybrid Blanket-Pu Production . . . . . . . . . . . 9 TETR-Hybrid Blanket-Pu Production/T Breeding . . . . . . . . . . . . . 10 Present Worth Benefits for a Fusion Power Plant as a Function of Plant Availability Date. . . . . . . . . . . . . . . . . . . 16


Tensile Properties $\left(20^{\circ} \mathrm{C}\right)$ of Nickel, $316 \mathrm{SS}$, and Niobium Wire (0.18) Irradiated with $(D, T) \cdot$ Neutrons 
PACIFIC NORTHWEST LABORATORY

FUSION ENERGY RESEARCH

OCTOBER THROUGH DECEMBER 1976

ERUA RESEARCH AND DEVELOPMENT REPORT

\section{SUMMARY}

The control of thermonuclear reactions is looked upon as the ultimate source of hightemperature energy. Success in the containment of fusion plasma has encouraged scientists to look beyond the confirmation of scientific feasibility to the identification of fusion reactor engineering problems that need solutions before demonstration plants can be built. Some fundamental and applied scientific problems could limit thermonuclear reactor development even after scientific feasibility is attained. Research at PNL continues to emphasize research in these development and technology areas.

The capability of a conceptual, $\mathrm{UO}_{2}$-fueled; outside blanket to produce power, plutonium, and tritium in the Tokamak Engineering Test Reactor (TETR) were determined in a fusion- . fịssion hybrid development study being made in cooperation with the University of Wisconsin... Plutonium production rates and tritium breeding performance were also evaluated for the conceptual TETR hybrid blanket using various technologically advanced fuels. In a PNL-PPPL study to develop a hybrid reactor using the Two Component Torus (TCT), structural and thermal stresses were analyzed for a double-wall design of the reactor first wall. Results indicate that cycling thermal stresses would be within acceptable limits with the use of roomtemperature cooling water. Other efforts in the TCT design study are identifying the controlling failure mode of the first wall and evaluating the integrity of the fuel slugs under thermal cycling conditions.

The levels of actinide contamination were calculated for fissile fuel produced by fusion neutrons. The preliminary evaluation is that ${ }^{233} \mathrm{U}$ produced with a blanket containing $\mathrm{ThO}_{2}$ would have a significantly greater magnitude of actinide contamination than ${ }^{239} \mathrm{Pu}$ produced with a blanket containing $\mathrm{UO}_{2}$. This difference and $239_{\mathrm{Pu}} \mathrm{s}$ high fissile content appear to make ${ }^{239} \mathrm{Pu}$ the preferable product for breeding in hybrid blankets.

The present worth benefits for a fusion power plant and the present worth costs of fusion research and development were estimated as functions of the date when fusion power plants would become commercially available. Preliminary analysis indicates an optimum commercial introduction date (maximum benefit-to-cost ratio) before the year 2000.

A task was initiated to scope experimental needs and to develop design analys is tools. for heat transfer and fluid flow in fusion reactor technology.

In the area of surface effects research, preliminary fluence data in (D,Be) neutron sputtering experiments at the University of California-Davis have indicated a sputtering yield of $28 \times 10^{-6}$ Atoms $/ n$ for gold sputtering targets. Equipment is being assembled to study the blistering effects of multiple-angle, helium ion irradiations using quasi-continuous energy spectra. In a study characterizing material transfer during different discharge 
cleaning modes of UCLA's Microtor, graphite collector samples have been prepared and inserted in Microtor. Sputter depth profiles of oxygen, carbon, and iron found on the surface of a glass collector placed in Microtor showed that relative concentrations varied with depth in a way that could be related to Microtor's operation history.

In studies of the effect of radiation on mechanical properties, the radiation hardening threshold for MRC Marz grade nickel wire irradiated with $(D, T)$ neutrons at $20^{\circ} \mathrm{C}$ was determined to be $22 \times 10^{16} \mathrm{n} / \mathrm{cm}^{2}$. No hardening was observed for 316 stainless steel wire irradiated at a fluence of $6 \times 10^{16} \mathrm{n} / \mathrm{cm}^{2}$. Neutron radiation hardening data for PNL niobium wire showed two yield points, one similar to LLL niobium data, and another, higher yield point. Experiments are being planned to determine the reasons for this yield point discrepancy.

In materials development studies, some graphite cloths irradiated to a neutron fluence of $1 \times 10^{22} \mathrm{~cm}^{-2}$ EFF at $470^{\circ} \mathrm{C}$ accommodated a shrinkage approaching $20 \%$ in the axial direction of the fibers with no apparent deterioration. The third of three irradiations in a task to correlate damage production for graphites in fission and fusion reactor spectra has been completed. Methods of cleaning the surface of a ${ }^{14} \mathrm{C}$-labeled carbon sample are being developed prior to neutron sputtering measurements. The carbon and graphite studies are aimed at the development of a liner material for placement between the fusion reactor plasma and the first structural wall. In evaluation of electrical insulators for fusion reactor applications, work has continued in the development of acoustic emission techniques for determining prebreakdown behavior and failure mechanisms in dielectric materials. Research objectives were considered for experiments to determine the effects of porosity and helium buildup on the dielectric breakdown strength of electrical insulators. Sample and equipment preparations are in progress.

The avallable fusion reactor design concepts have been analyzed to determine the probable interactions with the environment and the resultant environmental effects. The environmental analysis prepared by PNL for the fusion program has been published along with eighteen supporting reference documents. PNL has begun an effort this quarter to define the scope of a fusion reactor safety program plan and to identify the basic technology necessary to prepare a comprehensive safety analysis report on a fusion power plant. Contacts were initiated with other laboratories engaged in fuston safety research, and an investigation was started to examine the relevance of existing fusion reactor safety criteria to the fusion program.

PNL staff are currently teaching a course sequence for the three quarters of the 1976-77 academic year as a part of the University of Washington's graduate study program in Nuclear Engineering. The present quarter includes an introduction to plasma engineering and its application to controlled thermonuciear fusion. 


\section{FUSION SYSTEMS ENGINEERING}

PNL's effort in Fusion System Engineering comprises research and development aimed at solving some of the major technological problems of bringing fusion power systems on-line to fulfill U.S. energy needs. It is necessary that these engineering problems be given attention early enough in the fusion program to properly identify and solve them so that they do not limit the development and implementation of fusion reactors in commercial power production. Work reported this quarter includes continued design and development studies for the fusion-fission hybrid reactors, an economic analysis to develop information needed to establish an optimum R\&D schedule for magnetically confined fusion systems, a new task on the development requirements of heat transfer and fluid flow, and a task on the development of nuclear data standards for DMFE programs.

In cooperation with the University of Wisconsin PNL is defining and evaluating a fissile breeding outside blanket for the Tokamak Engineering Test Reactor (TETR) based upon near-term technological developments that could be implemented in the middle or late 1980's. With these constraints, uranium dioxide $\left(\mathrm{UO}_{2}\right)$ has been identified as the fertile breeding material for production of plutonium, and the capability of a conceptual, $\mathrm{UO}_{2}$-fueled, outer blanket to produce power, plutonium, and tritium has been determined. Plutonium production rates and tritium breeding performance were also assessed in calculations using the conceptual TETR hybrid blanket with various technologically advanced fuels - UMo, UC, and $\mathrm{U}_{3} \mathrm{Si}$.

A coordinated effort between PNL and the Princeton Plasma Physics Laboratory is being completed on the conceptual design of a fission-fusion hybrid reactor based on a Two Component Torus (TCT). Preliminary analyses indicate that the use of room-temperature cooling water may be possible in a double wall concept introduced by PNL as a firstwall design. Low temperature differentials through the wall $\left(\sim 25^{\circ} \mathrm{C}\right)$ and between the inner wall surface and mean fluid temperature $\left(9^{\circ} \mathrm{C}\right)$ in this design are within acceptable limits of cycling thermal stresses. Steady-state analysis of the converter region using a modified computer modeling code indicates that satisfactory cooling of the converter region (which consists of 316 SS tube, UMo annular slugs, and helium coolant) can be accomplished for lengths of one-sixth of the major circumference. Other modeling programs have been developed to identify the controlling failure mode of the first wall and to evaluate the integrity of the fuel slugs under thermal cycling conditions.

PNL has made a preliminary evaluation of the quality of fissile fuei produced by fusion neutrons, based on the degree to which the fuel is contaminated with undesirable isotopes. Calculations were made for a blanket containing either $\mathrm{ThO}_{2}$ or $\mathrm{UO}_{2}$ to produce

${ }^{233} \mathrm{U}$ or ${ }^{239} \mathrm{Pu}$, respectively. The magnitude of actinide contamination appears to make ${ }^{233} \mathrm{U}$ production economically unattractive, while high fissile content and the low quantity of waste products appear to make plutonium the preferable product for breeding in hybrid blankets. 
DMFE comments were received on a revised draft of the PNL document describing the design, operation, and economic information that should be included in fusion system design studies. A section on environmental information requirements is being.removed, and an example of costing for a typical power plant is being added as a result of those comments.

Economic analysis by Vashon and Nichols of the University of Texas indicates that accelerated R\&D expenditures through the use of parallel programs could bring about faster achievement of the technological milestones necessary for introducing magnetically confined fusion technologies. This would mean increased R\&D costs but earlier introduction of potentially cost-saving fusion power plants. Conversely, an extended R\&D period would have greater cost efficiency in the research process but would delay the possible cost benefits from the fusion power plants. The present worth benefits and R\&D costs were estimated for various dates of power plant introduction. Preliminary analysis indicates an optimum introduction date (maximum benefit-to-cost ratio) before the year 2000, regardless of the discount rate used to estimate the present worth benefits and R\&D costs.

Studies were initiated this quarter to develop design analysis tools and to scope experimental needs for the definition and assessment of heat transfer and fluid flow development requirements for the base technology of fusion reactors. Current documentation on The Next Step/Experimental Power Reactor designs have been identified.

In a task to participate in the development of current best-estimate nuclear data files for DMFE technology programs, a series of meetings were attended to discuss data needs. 
SYSTEMS STUDIES

System studies focus on providing key technical and economic information for planning and analyzing the fusion power program. One concept under study in the national fusion program is the fusion-fission (hybrid) system, which offers a possible near-term application of the fusion principle. The PNL studies of the hybrid are continuing to provide a rational basis for evaluating the merits of this concept in the nation's energy economy. A cooperative effort between Princeton Plasma Physics Laboratory (PPPL). and PNL is being completed on the conceptual design of a hybrid based upon a Two Component Torus (TCT). (1) This concept utilizes intense neutral deuterium beams to drive a tritium Tokamak plasma, and it provides the basis upon which the Tokamak Fusion Test Reactor (TFTR) ${ }^{(2)}$ has been designed. Another cooperative effort with the University of Wisconsin is underway to evaluate the plutonium breeding capability of perhaps a more near-term but yet smaller device--the Tokamak Engineering Test Reactor (TETR) ${ }^{(3)}$ which is also based upon a TCT. These studies are nearing completion with the issuance of draft topical reports targeted for the next quarter.

Standard economic analyses procedures and data bases are being established to develop optimum-cost time estimates for the introduction of advanced fusion power plants and to assure compatibility of cost estimates between fusion plants and competitive systems. Studies of the energy marketplace are being made to estimate the competitiveness of fusion power systems and establish target costs for flision reactors.

\section{TETR-HYBRID SCOPING STUDY}

V. L. Teofilo, R. T. Perry, B. R. Leonard, Jr., M. A. McKinnon

The TETR design study of Tokamak to produce a high neutron flux for engineering testing has recently been completed. ${ }^{(4)}$ The objective of the TETR-Hybrid study, being done in cooperation with the University of Wisconsin, is to define and evaluate a fissile breeding outside blanket for TETR (see Figure 1) based upon near-term technological developments that could be implemented in the middle to late 1980's. With this principal objective in mind, the fertile breeding material identified for the maximum production of plutonium ( $\mathrm{Pu})$ is uranium oxide $\left(\mathrm{UO}_{2}\right)$.

In addition to the evaluation of $\mathrm{UO}_{2}$, the relative breeding performance of technologically advanced fuels (e.g., metals, carbides, and silicides) has been evaluated for the defined outer TETR blanket. In order to estimate the requirements for upgrading TETR for possible commercial $\mathrm{Pu}$ and power production, the capability of the defined $\mathrm{UO}_{2}$-fueled outer blanket to breed tritium $(T)$ and to produce power has been determined.

COMPUTATIONAL METHODOLOGY

The ANISN code has been run in a one-dimensional, vertical cylindrical geometry. Thirty neutron groups in an $\mathrm{S}_{8}-\mathrm{P}_{3}$ calculation was employed. The neutron source was space 


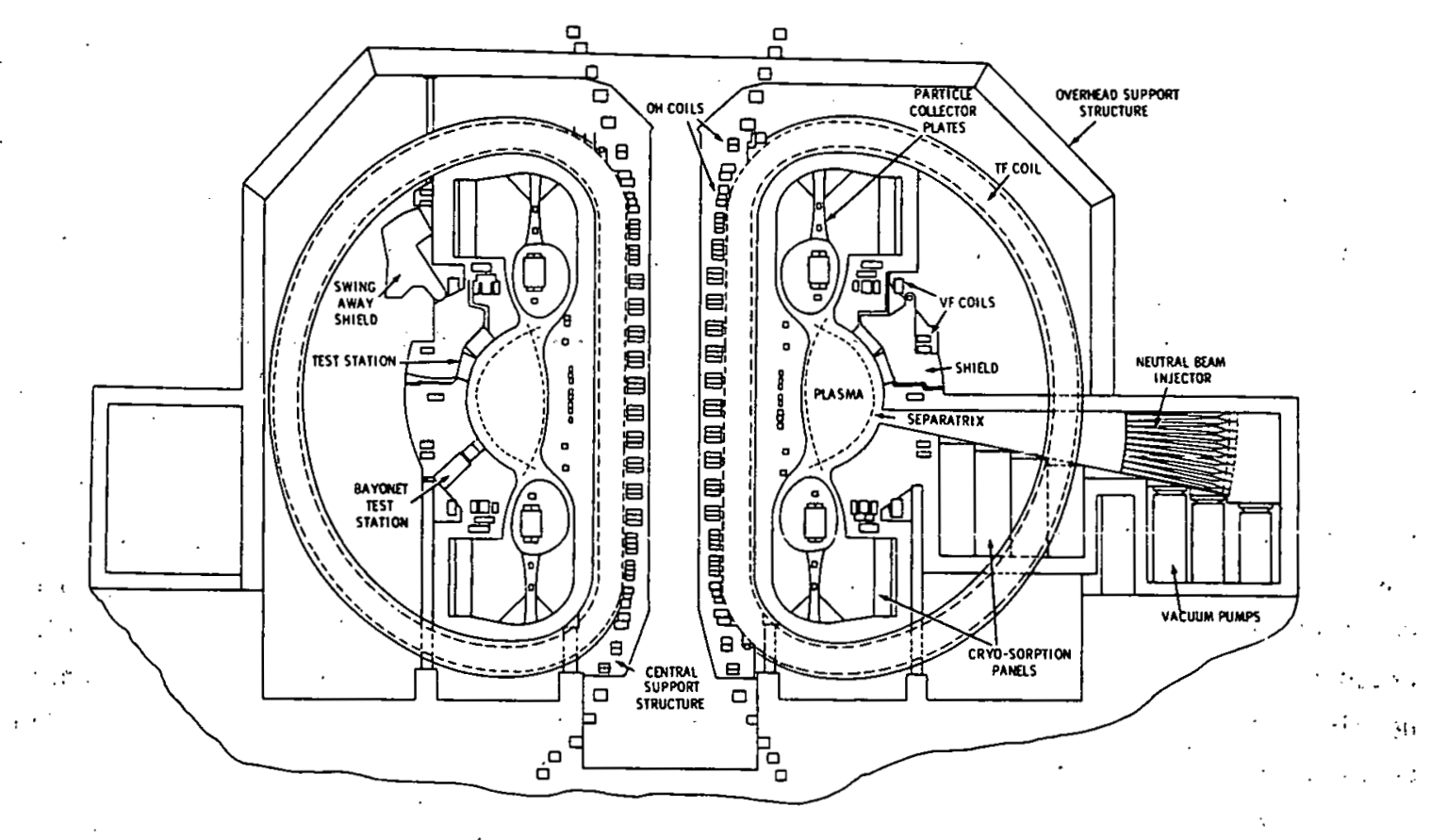

FIGURE 1. Cross Section View of TETR ${ }^{(4)}$

and energy dependent. The blanket schematic used for the calculations is shown in Figure 2. Because of cross section accessibility, stainless steel was substituted from the initial TETR design for insulation and the coils. The boundary conditions used were reflective for inner side of the torus and vacuum for the outer side of the torus.

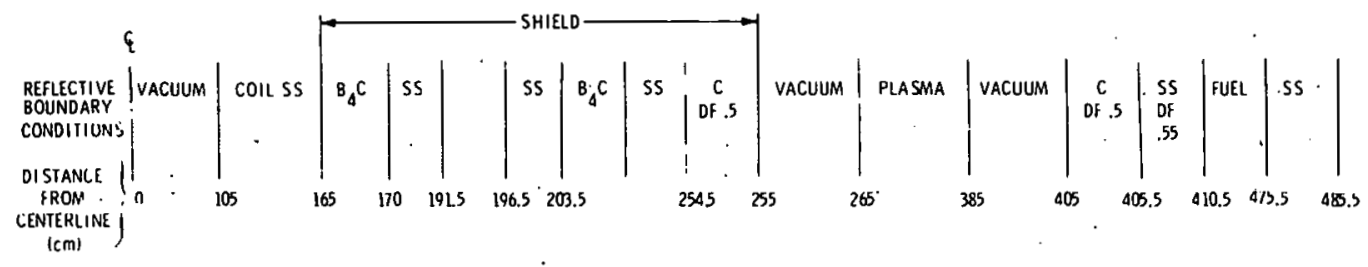

\section{FIGURE 2. Blanket Schematic}

The first wall and coolant channels on the outside blanket were estimated to be $5 \mathrm{~cm}$ thick containing 55\% SS. In each case, a volume fraction of $10 \%$ SS was used as an estimate of the cladding and structural material requirements.

Several different fuels, $U_{2}, U M o, U C$, and $U_{3} \mathrm{Si}$, were used in various calculations, the object of which was to determine the maximum ${ }^{239} \mathrm{Pu}$ production per source neutron through a volume fraction parameterization of fuel, structure, and coolant. Natural uranium was employed in each of the fuels. The ${ }^{235} U$ and ${ }^{238} U$ cross sections were spatial self-shielded using a geomtry from previous calculations. 


\section{BLANKET LAYYUT}

A preliminary layout for a practicable modular blanket design for containing $\mathrm{UO}_{2}$ fuel pins was identified. For the outer blanket region of TETR this concept assumes a $65-\mathrm{cm}$ blanket the thickness of which is restricted.by a minimum $10-\mathrm{cm}$ proximity to any normal poloidal field coil (see figure 3 ). The modules are $3.5 \mathrm{~cm}$ from the $316 \mathrm{SS}$ vacuum wall in order to permit adequate volume for helium cooling the first wall. They are divided into modular sections which contain $316 \mathrm{SS}$ clad, helium-cooled, $\mathrm{VO}_{2}$, fuel pins and which are separated by both the poloidal field coil. on the horizontal midplane, as well as the beam ports whose angle of penetration prohibit any uniform modular design between adjacent ports except in only one $45^{\circ}$ sector (see Figure 4 ).



FIGURE 3. Vertical Cross Section of TETR Showing Hybrid Blanket Modular Layou' ' 


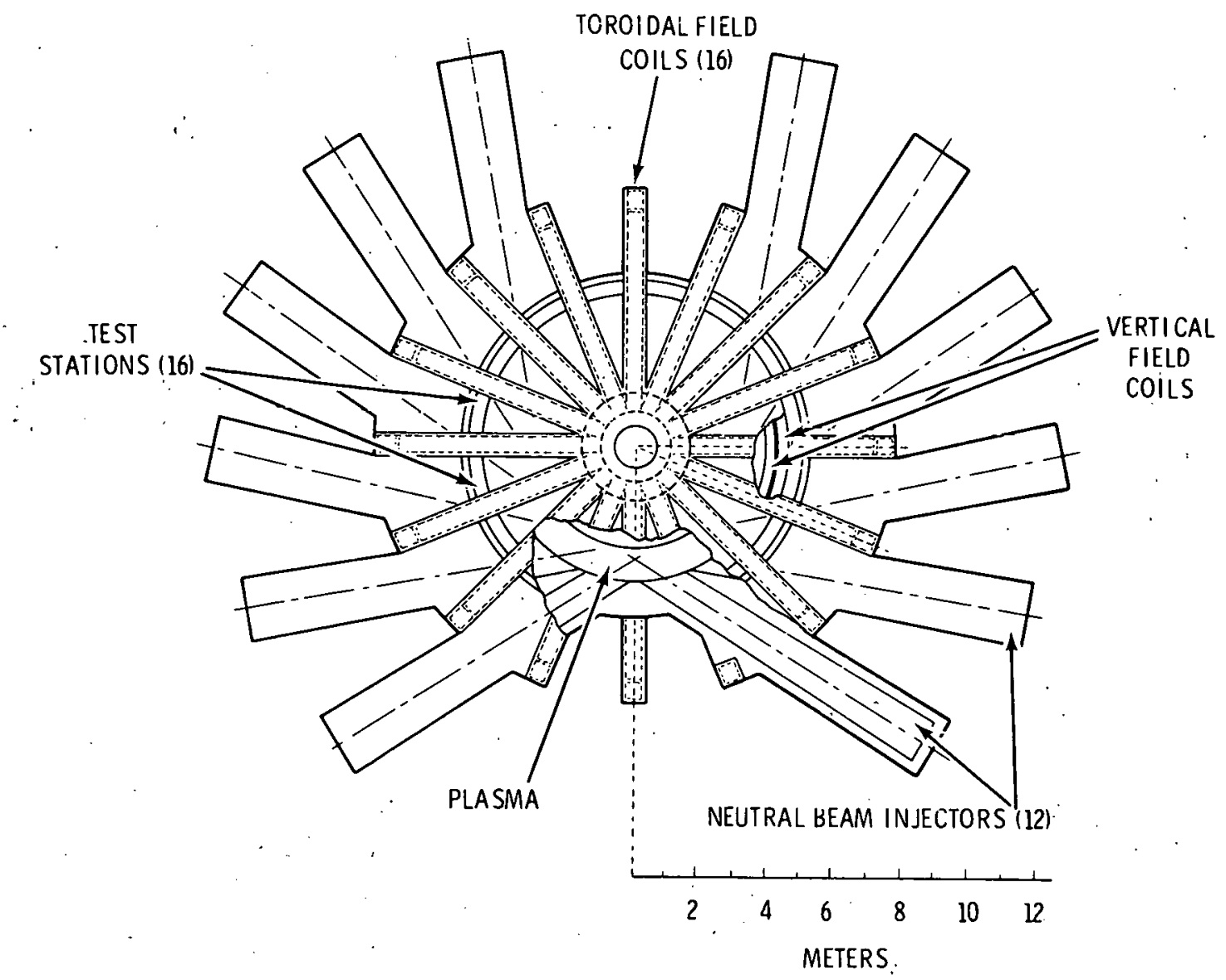

FIGURE 4. TOP View of the TETR $(4)$

\section{$\underline{U O}_{2}$-FUELED BLANKET}

For the geometry of the $65-\mathrm{cm}$ conceptual modular blanket design, the ANISN code was run for the volume fraction parameterization to determine the maximum Pu production rate using $\mathrm{UO}_{2}$ fuel. The resulting Pu production Pu production rates, which neglect depletion, are tabulated in Table 1.

TABLE 1. $\quad \mathrm{UO}_{2}$-Fueled TETR-Hybrid Blanket-Pu Production

\begin{tabular}{|c|c|c|c|c|c|c|}
\hline vol\% U02 & $\begin{array}{r}v 01 \% \\
316 \quad 5 S \\
\end{array}$ & vol\% Void & $\begin{array}{l}\text { Fissions } \\
\text { per } \\
\text { Fusion } \\
\end{array}$ & $\begin{array}{c}\text { Pu Atoms } \\
\text { Produced per } \\
\text { Fusion } \\
\end{array}$ & $\begin{array}{l}\quad \mathrm{Pu} \\
\text { Production } \\
\text { Rate, } \mathrm{kg} / \mathrm{yr}\end{array}$ & $\begin{array}{c}\text { Average } \\
\text { Blanket } \\
\text { Power, } \\
\text { MWt }\end{array}$ \\
\hline 0.2 & 0.1 & $.0: 7$ & 0.1784 & 0.700 & 394 & 434 \\
\hline 0.3 & 0.1 & 0.6 & 0.2209 & 0.923 & 520. & 542 \\
\hline 0.5 & 0.1 & 0.4 & 0.2668 & 1.160 & 563 & 637 \\
\hline 0.7 & 0.1 & 0.2 & 0.2879 & 1.260 & 709 & 680 \\
\hline 0.9 & 0.1 & 0 & 0.2993 & 1.307 & 736 & 702 \\
\hline
\end{tabular}

In computing these production rates, the effective neutron source strength of the TETR plasma was reduced from the $214 \mathrm{MW}$ instantaneous neutron power $\left(9.51 \times 10^{19} \mathrm{n} / \mathrm{sec}\right)$ to 
to $7.78 \times 10^{19} \mathrm{n} / \mathrm{sec}$ due to losses through the divertor channels and beam ports as well as the lack of fertile-fueled submodules in the regions of the poloidal field coil on the horizontal midplan and beam ducts. In addition, the power duty cycle (0.8275) and plant, factor (0.7) were taken into account. The blanket power, also averaged over a duty cycle, is due to fissions in the fuel and $60 \%$ of the effective $14-\mathrm{MeV}$ source neutrons which are assumed to lose all of their energy in the blanket. Gamma radiation due to activation is neglected. We note the performance of the 70 vol\% $\mathrm{UO}_{2}$-fueled blanket as producing about $700 \mathrm{~kg} \mathrm{Pu} / \mathrm{yr}$ while generating about 700 MWt of power in the blanket alone for an effective multipliçation of $\sim 7$ for the $100 \mathrm{MW}$ of neutron power which enter it.

\section{ADVANCED FUELS}

In order to assess the relative $\mathrm{Pu}$ production rates of fertile fuel, which could be available with the advances in development and technology expected by the 1990s, a volume fraction parameterization was performed with the ANISN code and the geometry of the conceptual TETR hybrid blanket for various advanced fuels (see Table 2).

TABLE 2. Advanced Fueled TETR-Hybrid Blanket-Pu Production

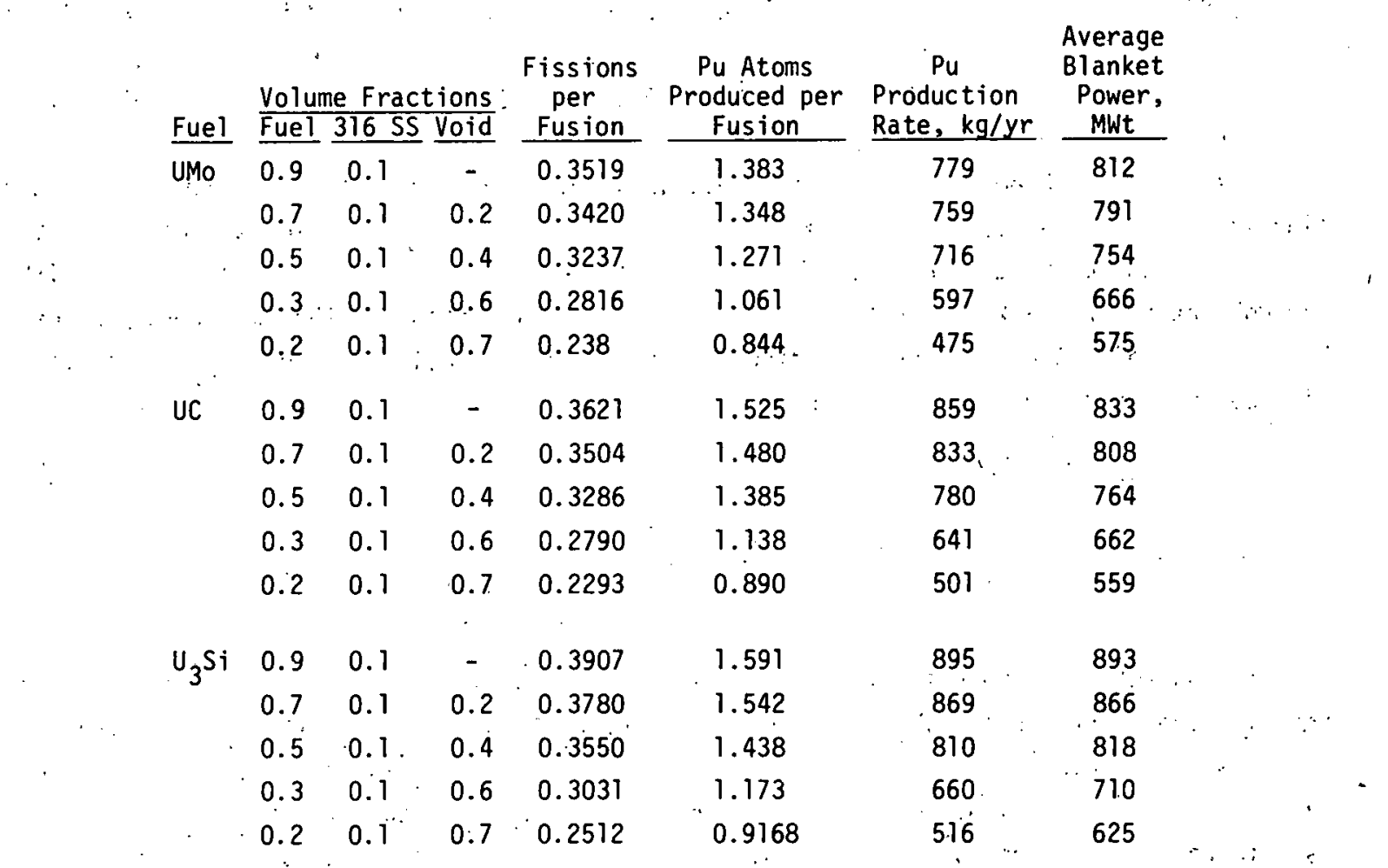

As compared to the $\mathrm{UO}_{2}$-fueled base case, the $\mathrm{Pu}$ and power producing rates of the 70 vol\% advanced fueled blanket cases are approximately $10 \%$ greater for UMo fuel, $20 \%$ greater for UC fuel, and $25 \%$ greater for $\mathrm{U}_{3} \mathrm{Si}$ fuel. 


\section{IRITIUM BREEDING}

The tritium breeding performance of the defined TETR-Hybrid blanket fueled with $\mathrm{UO}_{2}$ or the best advanced fuel $\left(\mathrm{U}_{3} \mathrm{Si}\right)$ was computed for various $T$ breeding volumes outside the fertile to fissile convertor region but within the blanket modules. The breeder consists of $25 \% \mathrm{Li}_{2} 0$ having a natural (7\%) ${ }^{6} \mathrm{Li}$ isotopic content, and 45 vol\% carbon with 10 vol\% 316 SS and 20 vol\% void for helium coolant. The convertor contained the base case $70 \mathrm{vol} \%$ of $\mathrm{UO}_{2}$ fuel, with 10 vol\% 316 SS and 20 vol\% void. The results are tabulated in Table 3.

TABLE 3. TETR-Hybrid Blanket-Pu Production/T Breeding

\begin{tabular}{|c|c|c|c|c|c|c|c|}
\hline Fue 1 & Pu Breeder & I Breeder & $\begin{array}{c}\text { T Atoms } \\
\text { Produced } \\
\text { per } \\
\text { Fusion } \\
\end{array}$ & $\begin{array}{c}\text { Fissions } \\
\text { per } \\
\text { Fusion } \\
\end{array}$ & $\begin{array}{c}\text { Pu Atoms } \\
\text { Produced } \\
\text { per } \\
\text { Fusion } \\
\end{array}$ & $\begin{array}{l}\quad P u \\
\text { Production } \\
\text { Rate, } \mathrm{kg} / \mathrm{yr}\end{array}$ & $\begin{array}{c}\text { Average } \\
\text { Blanket } \\
\text { Power, } \\
\text { MWt } \\
\end{array}$ \\
\hline \multirow[t]{3}{*}{$\mathrm{UO}_{2}$} & 39 & 26 & 0.1145 & 0.2731 & 1.1244 & 633 & 657 \\
\hline & 26 & 39 & 0.2852 & 0.2472 & 0.9201 & 518 & 608 \\
\hline & 13 & 52 & 0.5713 & 0.1822 & 0.5416 & 305 & 490 \\
\hline \multirow[t]{3}{*}{$\mathrm{U}_{3} \mathrm{Si}$} & 39 & 26 & 0.1090 & 0.3658 & 1.412 & 795 & 846 \\
\hline & 26 & 39 & 0.3099 & 0.3409 & 1.199 & 675 & 804 \\
\hline & 13 & 52 & 0.6002 & 0.2672 & 0.7651 & 431 & 657 \\
\hline
\end{tabular}

The maximum $T$ breeding ratios obtained, about 0.6 , correspond to more than a $50 \%$ reduction in the Pu.production rate, as expected. It is possible to increase this ratio to about 1.0 by both enriching the ${ }^{6} \mathrm{Li}$ isotopic content of the $\mathrm{Li}_{2} \mathrm{O}$ and running natural liquid lithium through the inner blanket. Whether this can be accomplished and at the same time produce $\mathrm{Pu}$ at a rate of $450 \mathrm{~kg} / \mathrm{yr}$, corresponding to one PWR charge fueled with pure, first cycle Pu, will be evaluated during the next phase of this study.

\section{ICT HYBRID CONCEPTUAL DESIGN STUDIES}

D. T. Aase, R. T. Perry, M. C. C. Bampton, R. A. McCann

The objective of this study is to develop a conceptual design of a hybrid based on current Two Component Torus (TCT) technology. If the concept appears promising, a reference design will be developed. The ground rules are: 1) to optimize on production of fissile material, consistent with the requirement that a tritium breeding ratio in excess of one is obtained, 2) to constrain the technology to that available to construct a machine in the early 1990s, and 3) to minimize the capital costs.

The Tokamak Fusion Test Reactor (TFTR) ${ }^{(2)}$ will be the first fusion device using magnetic plasma containment to yield neutrons from the fusion process. The TFTR uses the TCT concept for plasma heating and containment. While the concept is expected to yield a near Lawson Plasma, it is not expected to extrapolate to a net exporter of electrical power. One potentially feasible way to commercially utilize this technology, however, is to design a hybrid 
device which uses the neutrons from the TCT device to breed fissile material for use in fission reactors and to produce some power directly. A coordinated effort between scientists and engineers from PPPL and PNL is underway to evaluate the potential of this concept and develop a conceptual design.

A double-walled configuration of 316 SS tube was introduced by PNL and identified as a primary candidate for the first wall of the toroidal plasma chamber. It was assumed to contain a maximum of about 10 vol\% SS. Preliminary structural and thermal hydraulics analysis have been performed. Computer analyses used the computer code BOSOR4 for buckling under external pressure and $A X I S O L{ }^{(5)}$ for internal pressure between the double walls. The analyses indicate that the use of room-temperature cooling water may be possible. The cooling water temperature rise is $3.5^{\circ} \mathrm{C}$ for a mean velocity of $5.1 \mathrm{~m} / \mathrm{sec}$. The maximum temperature difference through the wall is approximately $25^{\circ} \mathrm{C}$ and the temperature difference between the inner wall surface and mean fluid temperature is about $9^{\circ} \mathrm{C}$. These temperature differentials are within acceptable limits of cycling thermal stresses.

In order to identify the controlling failure mode of the first wall, an ANSYS program mode $^{(6)}$ has been. set up with the following capabilities to represent a segment of the toroidal chamber:

- two walls connected by stiffeners with 4.0-in. spacing

- different pressures at each surface

- meridionally varying temperature on both walls.

This model differs from the AXISOL model by virtue, of being a shell representation of. a toroid structure. With the inclusion of radiation swelling effects, it will provide stress levels to assess the significance of:

- fatigue

- crack propagation

- creep rupture

- embrittllement:

The fabrication aspects of the first wall have been explored and a draft report is being' prepared.

The PNL COBRA. (7) code has been modified to model the converter region. This region is. modeled as a single 316 stainless steel tube (SST), uranium molybdenum annular slugs, and helium coolant. Thermophysical properties and a range of possible configurations have been identified. Steady-state analysis of the converter region, using the modified COBRA code . indicates satisfactory cooling can be accomplished for lengths of one-sixth of the major...: circumference. Preparation of the COBRA' code for transient calculations is currently underway in order to determine the change in pressure tube and fuel temperatures during the shutdown portion of the power cycle.

Two axisymmetric stress models have been developed to evaluate the integrity of the fuel slugs under thermal cycling conditions. One model investigates a section in the middle of the slug where conditions are axially uniform, and the second model investigates the ends of the slug where conditions are not axially uniform. A steady-state thermal condition is being applied. 
Thermophysical properties for the blanket region have been collected. Several heat transfer codes have been examined for suitability and one has been selected which will account for change of phase of the molten salt. Preliminary steady-state calculations suggest the need for several coolant paths inside the blanket to maintain acceptably low temperatures.

HYBRID STUDIES - THE QUALITY OF FISSILE FUEL BRED

$$
\text { IN A FUSION REACTOR BLANKET }{ }^{(8)}
$$

B. R. Leonard, Jr., U. P. Jenquin

A preliminary evaluation has been made of the quality of fissile fuel produced using fusion neutrons. The quality of the product is expressed as the degree to which the product is contaminated with undesirable isotopes. Calculations were made for a blanket containing either $\mathrm{ThO}_{2}$ or $\mathrm{UO}_{2}$ to produce ${ }^{233} \mathrm{U}$ or ${ }^{239} \mathrm{Pu}$, respectively. The rates of production of the product and by-product isotopes were tracked as a function of the irradiation time: For perspective on the quality of the fuel produced, the $U$ and Pu generated in the hybrid reactor are compared to the same products produced in fission reactors; namely plutonium produced in LWRs and LMFBRs, and ${ }^{233} \mathrm{U}$ produced in High Temperature Gas Cooled Reactors (HTGRs). The by-products were examined to determine the quantities and characteristics of radioactive waste associated with hybrid fisșile fuel production.

The hybrid reactor with a ThO ${ }_{2}$ blanket produces approximately $1.4 \mathrm{~kg}$ of $233_{\mathrm{JJ} / \mathrm{MT}}$ of thorium per 100 days of irradiation. The fissile content of the bred uranium is nearly $100 \%$, whereas HTGR fuel on an equilibrium cycle is $270 \%$ fissile.

The ${ }^{233} U$ fuel produced in a hybrid thorium blanket contains substantially higher concentrations of ${ }^{232} \mathrm{U}$ compared to ${ }^{233} \mathrm{U}$ produced in HTGRs. One of the isotopes in the ${ }^{232} \mathrm{U}$ decay chain is ${ }^{208} \mathrm{Tl}$ which emits a high-energy gamma ray. Shielding of this gamma ray is required to protect personnel involved in postreprocessing operations such as fabrication and transportation of the recovered uranium. In order to lower the ${ }^{232} \mathrm{U}$ concentration to maximum levels expected in the HTGR cycle $\left(0.12 \%{ }^{232} \mathrm{U}\right)$, the cycle length would have to be less than 70 days. However, under these conditions a higher fuel-cycle cost would result from increased blanket fabrication and reprocessing through-put per unit of recovered product. Although it was not within the scope of this study to quantify the significance of high ${ }^{232} U$ concentrations in the fission. fuel cycle, this may be a significant drawback to breeding ${ }^{233} \mathrm{U}$ in hybrid reactors.

Another consideration in the $\mathrm{Th}^{-233} \mathrm{U}$ cycle is the production of actinide by=products and the implications of these on management of radioactive residues. The high-energy neutrons generate approximately $0.4 \mathrm{~kg}$ of these isotopes $/ \mathrm{kg}$ of product ${ }^{233} \mathrm{U}$. The characteristics of these isotopes are such that they will require long-term waste management similar to that. required for high-level waste from reprocessing fission reactor fuels. 
The hybrid reactor with a $\mathrm{UO}_{2}$ blanket produces $1.4 \mathrm{~kg}$ of ${ }^{239} \mathrm{Pu} / \mathrm{MT}$ of uranium/100 days of irradiation. The fissile content of the bred plutonium is greater than $95 \%$. This is much higher than the $69 \%$ fissile plutonium obtained from the LWR uranium cycle or the $75 \%$ fissile plutonium obtained from the equilibrium LMFBR cycle. Since the high fissile plutonium would have to be used in a different manner than that proposed for LWR-produced plutonium, a study of the complete fuel cycle is necessary to ascertain the true economics of high, fissile. plutonium.

A major constraint in plutonium fuel fabrication is due to neutron emissions from $(\alpha, \hat{n})$ reactions with oxygen and light element impurities. The alpha activity results primarily from. ${ }^{238} \mathrm{Pu}$ decays; therefore, ${ }^{238} \mathrm{Pu}$ is an undesirable contaminant... Hybrid-produced plutonium contains less ${ }^{238} \mathrm{Pu}$ than LMFBR-produced plutonium or LWR-produced plutonium; hence, the hybrid plutonium is more valuable with respect to ${ }^{238} \mathrm{Pu}$ content.

Plutonium-236 is an isotopic contaminant with a half-life of 2.8 years and rapidly builds up the ${ }^{232} \mathrm{U}$ decay chain with its source of high-energy gamina rays. As: with ${ }^{232} U$ ' in the $\mathrm{Th}_{-}{ }^{233} \mathrm{U}$ cycle, this places additional personnel shielding requirements on fuel handling ' operations subsequent to fuel recovery. The ${ }^{236} \mathrm{Pu}$ concentration in hybrid-produced plutonium is three orders of magnitude. larger than in LMFBR- and LWR-produced-plutonium.

Approximately $0.14 \mathrm{~kg}$ of by-product actinides are produced per $\mathrm{kg}$ of plutonium recovered from 'a $\mathrm{UO}_{2}$ hybrid blanket. Essentially all of this by-product waste consists of ${ }^{237} \mathrm{~Np}:$ There is a factor of three more ${ }^{237} \mathrm{~Np}$ produced in a hybrid than that generated in an LWR and: a factor of four more than that generated in an LMFBR for equivalent masses of plutonium. On the other hand, there is virtually no americium or curium produced in a hybrid, whereas both the LWR and the LMFBR produce $0.07 \mathrm{~kg}$ of these elements for each $\mathrm{kg}$ of plutonium produced. As with the $\mathrm{Th}^{233} \mathrm{U}$ cycle, the characteristics of the actinide waste are such that they will require long-term waste management similar to that required for high-level waste from fission reactor fuels:

The results of these calculations indicate that plutonium breeding in hybrid blankets may be preferable to ${ }^{233} \mathrm{U}$ breeding. The contaminants of ${ }^{233} \mathrm{U}$ appear to be of a magnitude to make the product economically unattractive while the high fissile content and the low quantity of waste by-products appear to make plutonium attractive.: However, in order for the hybrid breeder to be competitive in the economic market place, the value of the fissile fuel it produces must offset its capital and operating costs. The entire fuel cycles require 'a considerably more detailed study to determine the synergistic relationships with specific fuel cycles, net energy balance, and radioactive waste management requirements.

The conclusion that ${ }^{233} \mathrm{U}$ breeding in a hybrid blanket is less attractive, is predicated on the assumption that a molten salt processing system is not developed. 


\section{PRELIMINARY ECONOMIC ANALYSIS}

\section{J. R. Young}

Design studies for fusion power plants are expected to be issued frequently during the development program. These studies will provide the basis for economic and environmental analyses which determine research needed to produce the most attractive designs. Use of past design studies for analyses has been difficult because of lack of information or inconsistent presentation of information.

Economic and environmental information requirements have been provided in a draft document prepared for the Division of Magnetic Fusion Energy. This document describes the related types of design, operation, and economic information that should be included in each design study and establishes certain basic general rules and assumptions that should be used in the development of that information. Provision of such information in design. studies will assure that the necessary data are available and that satisfactory comparisons of design concepts can be made. :

A revised draft of the information requirements document was prepared and forwarded to the Division of Magnetic Fusion Energy for comments. As the result of those comments, the section on environmental information requirements is being removed, and an example of costing for a typical power plant is being added.

\section{ECONOMIC REGIMES}

D. E. Deonigi, R. L. Engel

During the past year, Vanston and Nichols ${ }^{(9)}$ of the University of Texas have estimated the costs of achieving important technological milestones for magnetically confined fusion energy systems. Of particular interest is that these estimates also include the impact of rate of expenditure. In general, it is estimated that. accelerated expenditures through the use of. parallel programs can produce earlier achievement of the technology milestones. This would lead to the. possible introduction of magnetically confined fusion technologies at an earlier date; however, greater efficiency may be achieved in the research process by extending the research and development period, which would reduce the total expenditure at the expense of later introduction. of the potentially cost-saving advanced fusion power plants.

Figure 5 shows the cumulative present worth cost of research and development estimated by Nichols as a function of availability date at a 7.5\%/annum and a 10\%/annum discount rate. The two discount rates allow direct comparison with calculations made using the linear programming model of the U.S. electrical generating system, which estimates the benefits of fusion power plants as a function of availability date.

The benefits of fusion power are estimated by using a scenario for the development of competing energy sources consistent with that presented in the recent LMFBR cost-benefit 




FIGURE 5: Cumulative Present Worth Cost of R\&D as a Function of Fusion Power Plant Availability Date

study (ERDA 38). (10) However, some modifications include higher LMFBR cost (LWR plus $\$ 100 / \mathrm{kWe}$ ) and a 12-year doubling time consistent with the utility opinion collected in a survey of the Electric Power: Research Institute fussion committee. This scenarios is, therefore, generally consistent with that presented in previous quarterly reports dealing with the hybrid power plant.

Figure 6 illustrates the calculated present worth benefits for a fusion. power plant having costs equal to the LMFBR plus $\$ 30 / \mathrm{kWe}$. This figure includes cases for introduction at various dates with discount rates of $7.5 \%$ and $10 \%$ consistent with the cost estimates in Figure 5. The benefit/cost ratios (estimated cost benefits/estimated R\&D costs) are shown in Table 4 for the same discount rates in the same years. The Rơ costs in Figure 5 are extrapoalted beyong the year 2000 data supplied by Nichols, based on the assumption that at some point earlier than $2000(21990)$ the R\&D costs would be extremely large due to the need for many parallel efforts. Benefit growths are not as fast from 1990 to 2000 as from 2000 to 2010 because the fusion plant does not compete as well in the early years due to the low cost fuel still available from coal and nuclear plants. These results indicate that the optimum time of introduction is before year 2000 and that the point of maximum benefit-cost ratio seems to be independent of the discount rate used. Benefits increase at uniform percentage rates for every ten years of earlier availability. The network' analysis performed " by Nicols as well as the benefit analysis has some uncertainties. Nichols indicates. that an uncertainty of $\pm \$ 1$ bilition is typical for R\&D costs, while benefit simulation indicates a $\pm 50 \%$ uncertainty. 


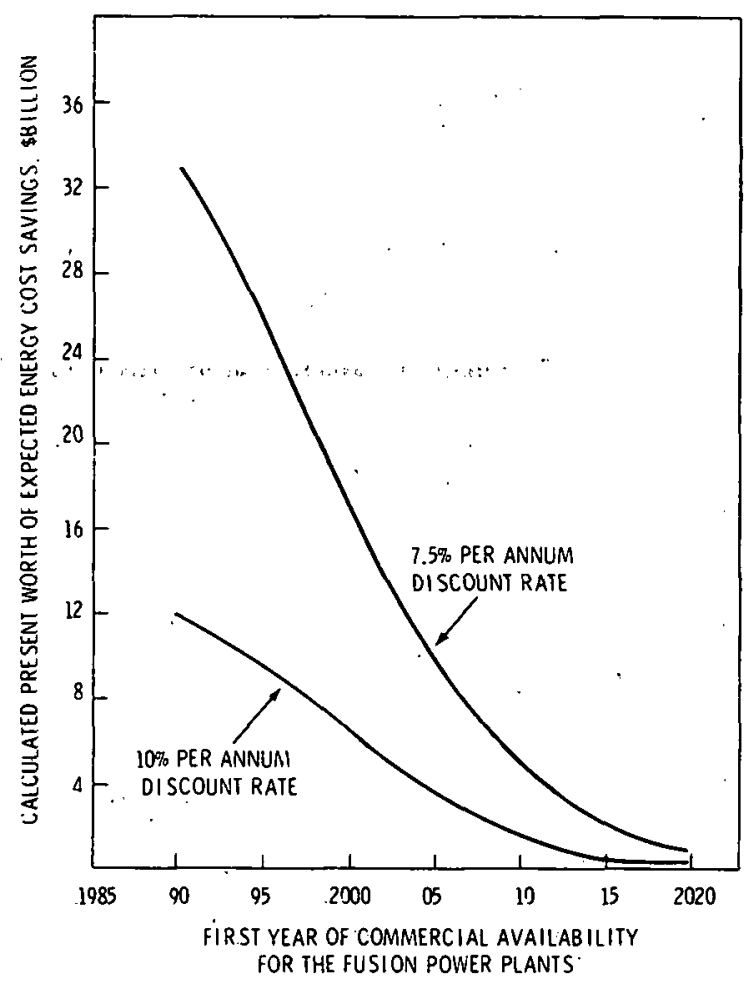

FIGURE 6. Calculated Present Worth Benefits for a Fusion Power. Plant as a Function of Plant Availability Date

TABLE 4. Present Worth Benefit/Cost (B/C) as a Function. of Availability Date

\begin{tabular}{|c|c|c|c|c|c|c|}
\hline \multirow{2}{*}{$\begin{array}{l}\text { Availabjlity } \\
\text { Date } \\
\end{array}$} & \multicolumn{3}{|c|}{$7.5 \%$ Discount Rate } & \multicolumn{3}{|c|}{$10 \%$ Discount Rate } \\
\hline & $\begin{array}{l}\text { R\&D Costs, } \\
\text { S Billions }\end{array}$ & $\begin{array}{r}\text { Benefits, } \\
\text { \$ Billions } \\
\end{array}$ & $\underline{B / C}$ & $\begin{array}{l}\text { R\&D Costs, } \\
\$ \text { Billions }\end{array}$ & $\begin{array}{l}\text { Benefits, } \\
\text { \$.Billions }\end{array}$ & B/C \\
\hline $\begin{array}{c}1990 \\
\text { (Estimate) }\end{array}$ & 13 & 33.0 & 2.6 & 8.5 & 12.0 & $\cdot 1.4$ \\
\hline 2000 & 4.85 & $19.0^{\circ}$ & 3.9 & 3.62 & 5.9 & 1.6 \\
\hline 2010 & 1.96 & 4.4 & 2.2 & 1.43 & 1.4 & 1.0 \\
\hline 2020 & $0.8 \dot{8}$ & 0.9 & 1.0 & 0.56 & 0.4 & 0.7 \\
\hline
\end{tabular}

The very preliminary analysis presented above is an attempt to develop information to establish an optimum rate at which R\&D for magnetically confined fusion systems should be purused. This analysis indicates that introduction of the fusion power plants prior to the year 2000 would produce the greatest benefits, especially when compared with introduction in the year 2020. Of particular significance is the fact that this conclusion seems to be independent of the discount rate used in the analysis.

During the next quarter, a more detailed and refined analysis of this particular situation will be pursued. 
Blanket and Shield Engineering studies focus on developing valid technical-bases. for reactor design and transferring the technology to industry capability. Work was initiated on developing design analysis tools for heat transfer and fluid flow and. to scope experimental needs. PNL is also participating in the nuclear data community to define nuclear data needs and develop best-estimate nuclear data files for DMFE technology programs.

\section{HEAT TRANSFER AND FLUID FLOW}

A. M. Sutey, D. T. Aase

The objective of these studies is to develop design analysis tools and to scope experimental needs to investigate, define, and assess the heat transfer and fluid flow development requirements for the base technology of fusion reactors.

This task was initiated this quarter. For FY77, the scope of work will emphasize heat transfer and fluid flow methods development and implementation in support of Experimental Power Reactor (EPR) and The Next Step (TNS) designs. To date, current documentation on TNS/EPR designs are being reviewed and the appropriate contacts in each design organization have been identified.

\section{NUCLEAR DATA STANDARDS}

B. R. Leonard, Jr.

The objective of this task is to participate in the development of current best-estimate nuclear data files for DMFE technology program.s During this quarter, a series of meetings were attended to discuss data needs. A meeting of the Cross Section Evaluation Working Group's (CSEWG) Nuclear Model Codes Subcommittee was held at the Hanford Engineering Development Laboratory, October 13-14 to compare nuclear model calculations by five laboratories on ${ }^{59}$ Co cross sections. These comparisons are relevant to the estimation of $p$ and $\alpha$ production to $40 \mathrm{MeV}$.

A specialist's meeting on Nubar (number of neutrons per fission) was held at BNL October 26 as a Standards Subcommittee meting of CSEWG to arrive at recommended values for fissile isotopes for ERDA's Evaluated Nuclear Data File/B-V. This was followed by the CSEWG and Standards Subcommittee meetings at BNL October 27 and 28 . A presentation was made to the Data Testing Subcommittee on PNL-evaluated thorium data for ENUF/B-V. A presentation was also made to CSEWG on long term radioactive dose from retired fission plants and the resultant need for a special file of decay data for LWRs, LMFBRs, and fusion reactors. The Standards Subcommittee reviewed the proposed agenda for the Symposium on Nuclear Data needs to $40 \mathrm{MeV}$ with $\mathrm{M}$. Bhat, of BNL, proposing changes in the agenda suggesting invited speakers in certain areas. 
At the Washington, DC ANS meeting November 14-19, an attempt was made to influence reversal of the position of the ANS Publications Committee on adoption of an ASTM standard on SI units. This is a problem for communication in nuclear physics. A reversal was effected, at least in large part. Also at the meeting a discussion on the status of thorium data was held with Bohn and Carpenter of ANL, who are interested in both fission and hybrid application. 




\section{MATERIALS RESEARCH AND RADIATION ENVIRONMENT SIMULATION}

The various materials and components of a fusion reactor will be subjected to extreme physical environments, intense fluxes of high energy neutrons, alpha particles, and ionic species as well as internally generated products of neutron-induced reactions, such as helium. PNL is examining the effects of these environments on candidate fusion reactor materials, using reactor irradiations and simulation techniques to: 1) determine parameters for sputtering and blistering at materials surfaces, 2) correlate changes in mechanical properties produced by light ions and fusion neutrons, 3) evaluate carbons and graphites fnr use as possible first-wall liner materials, and 4) determine the effects or porosity and helium buildup on the dielectric breakdown strength of electrical insulators.

PNL surface science work this quarter has included studies of fast-neutron sputtering, blistering effects of polyenergetic helium ions, and in-reactor material transfer during different discharge cleaning modes. Nuclear counting of the dosimeter foils used during the $(D, B e)$ neutron sputtering experiments at the University of California-Davis has furnished preliminary fluence data which imply a sputtering yield of about $8 \times 10^{-6}$ atoms $/ \mathrm{n}$ from gold sputtering targets. A new target which will allow a significant increase in useful neutron flux at the University of California's cyclotron has been purchased from LLL and is stated for use early in 1977. In a study of the blistering effects of continuous or quasicontinuous helium ion energy spectra, a programable energy degrader and equipment allowing simultaneous multiple-angle irradiations have been designed and are being assembled. Graphite collector samples for the discharge cleaning program have been prepared and are being inserted in Microtor at UCLA to study material transfer during different discharge cleaning modes. Preliminary examination of a glass collector that was in Microtor during many cycles and cleaning modes showed large amounts of oxygen, carbon, and iron on its surface; sputter depth profiling showed that relative concentrations varied with depth in a way that could be related to Microtor's operation history.

Mechanical properties studies continue at PNL to correlate the microstructures and radiation hardening produced by light ions and fusion neutrons. The light ion irradiation apparatus, helium flow system, and data readout equipment have been transported to the University of Washington Nuclear Physics Laboratory where beam diagnostics are planned for January of 1977 with proton irradiations for the $p^{+} /(D, T)$ neutron correlation experiment to follow. The radiation hardening threshold for MRC Marz grade nickel wire irradiated with $(D, T)$ neutrons at $20^{\circ} \mathrm{C}$ is approximately $2 \times 10^{16} \mathrm{n} / \mathrm{cm}^{2}$. Neutron radiation hardening data for PNL niobium wire showed a lower yield point, similar to LLL niobium data, but also an upper, enhanced yield point for PNL niobium. Further experiments are being planned to clarify the reasons for this upper yield point discrepancy. A cyclic irradiation creep experiment is being planned to follow the light ion/fusion neutron correlation experiment. The experiment will study the creep behavior of fusion reactor candidate materials under simulated operating conditions. 
Studies have continued to evaluate radiation damage, sputtering, and outgassing for carbons and graphites which could possibly be useful in preventing structural damage by shielding the first wall from the plasma. Preliminary measurements of thin graphite cloth samples irradiated to a neutron fluence of $1 \times 10^{22} \mathrm{~cm}^{-2}$ at $470^{\circ} \mathrm{C}$ indicate shrinkages approaching $20 \%$ have occurred in the axial direction of the fibers. Nevertheless, some types of cloth accommodated this shrinkage with no visual deterioration. All three irradiations in the task to correlate damage production for graphites in fission and fusion reactor spectra have been completed, but temperature excursions during the third irradiation may mean that it will have to be redone. Methods of cleaning the surface of a carbon sample labeled with ${ }^{14} \mathrm{C}$ are being developed prior to the start of neutron sputtering measurements. Equipment problems with the graphite degassing apparatus have been eliminated and measurements are now in progress.

Work has continued in the development of acoustic emission techniques for determining prebreakdown behavior and failure mechanisms in electrical insulators for fusion reactor applications. Research objectives were considered for experiments to determine the effects of porosity and helium buildup on the dielectric breakdown strength of insulators. Some specific insulators and a helium introduction method were chosen for initial investigation. Sample preparation and setting up of the experimental system are in progress. 
This work is examining the effects of the fusion reactor environment on surface and near-surface regions of reactor structures and the influence of plasma-wali: interactions on the plasma. Ions, neutral particles, neutrons, photons and electrons from the plasma will interact with exposed surfaces to produce effects such as physical and chemical sputtering, desorption, blistering, and re-emission. Material which leaves the wall due to these effects may then enter the plasma and cause loss of plasma energy through bremsstrahlung or line radiation. Erosion will weaken structural integrity and may adversely influence surfaces exposed to coolant in the cooling channels.

\section{SURFACE EFFECTS}

D. L. Styris, M. T. Thomas

Progress is reported this quarter for three programs being conducted by PNL surface science staff: ( $\mathrm{D}, \mathrm{Be}$ ) neutron irradiations are being used in determining neutron sputtering data; the blistering effects of polyenergetic $\mathrm{He}^{+}$irradiations-of niobium samples are being studied; and material transfer during different discharge cleaning modes is being examined in Microtor at UCLA.

Nuclear counting of the dosimeter foils used during the neutron sputtering experiments at the $(D, B e)$ neutron source of the University of California-Davis is still in progress. Data analysis techniques used to determine neutron fluences at $(D, B e)$ sources are those developed by Dr. M. Saltmarsh of ORNL. Preliminary results indicate that for each of the three experiments the gold sputtering target was irradiated to a fluence ( $E_{n}$ greater than $\sim 2 \mathrm{MeV}$ ) of $21.3 \times 10^{17}, 21.7 \times 10^{17}$, and $22.1 \times 10^{17} \mathrm{n} / \mathrm{cm}^{2}$, respectively. These preliminary fluence data imply a forward sputtering yield for $(\mathrm{D}, \mathrm{Be})$ neutrons (40-MeV deuterons) of about $8 \times 10^{-6}$ atoms $/ \mathrm{n}$. The useful neutron flux at the University of California-Davis's cyclotron could be increased significantly if the targets were closer to the Be and a higher deuteron current were used. The new water-cooled target purchased from LLL allows both objectives to be accomplished. This new target should be ready for use sometime early in 1977.

Our helium blistering program is designed specifically to study the effects of continuous or quasi-continuous helium ion energy spectra. Since the success of the preliminary experiments with a simple degrader foil, a programable energy degrader has been designed, and the assembly is near completion. In addition, a faraday cup-sample configuration which allows simultaneous multiple-angle irradiatons at temperatures up to $1000^{\circ} \mathrm{C}$ has been designed, the assembly of which is also near completion.

The emphasis in the discharge cleaning program has been in preparing collector samples for insertion in Microtor at UCLA. Surfaces of pyrolytic graphite have been characterized and have been found to be very stable in air if handled correctly. This stability makes 
pyrolytic graphite an ideal collector for discharge cleaning experiments where the analysis must be performed at a facility not connected to the Tokamak. A series of graphite samples have been mounted in stainless steel holders and are being inserted in Microtor to study material transfer during different discharge cleaning modes.

A glass collector that has been in Microtor during many cycles and various cleaning modes has been examined using Auger spectroscopy. Preliminary data showed large amounts of oxygen, carbon and iron on the surface. Sputter depth profiling showed that the relative concentration varied with depth in a way which could be related to Microtor's operation history.

- A representative from PNL's Surface Science group was represented at the Plasma Wall Interaction Symposium held in Julich, Germany, in October. Visits were made to the laboratories at Julich and Garching, and the Harwell and Culham laboratories in England. 
Structural materials in magnetic fusion reactors will be subjected to bulk radiation damage from energetic neutrons coupled with.cyclic temperatures and stresses. Irradiationinduced creep, fatigue, and embrittlement of materials are serious limitations on the design life of many fusion reactor components. An understanding of the specific effects of irradiation on creep, fatigue, and crack growth rates is necessary for the development and selection of alloys for these components; however, materials studies for fusion reactor applications are severely hampered by the lack of a high-flux, high-energy, large-volume irradiation facility. Charged particle irradiations of materials can help satisfy the flux and energy requirements for irradiation damage studies while lowering the necessary radiation levels (relative to neutronic irradiations) and offering the potential to control radiation parameters. A balanced program of light ion, fusion neutron, and fission neutron irradiation studies is underway to gain an understanding of the effects of a fusion neutron environment on the mechanical properties of materials.

\section{RADIATION ENVIRONMENT SIMULATION-MECHANICAL PROPERTIES}

\section{R. H. Jones, D. L. Styris}

It is desirable to: assess the ability of: light ions to simulate fusion neutron irradiation effects on mechanical properties before the advantages of charged particle irradiations are . pursued in irradiation damage studies. Of the large number of charged particles:available "for. such damage studies; $16 \mathrm{MeV}$.protons $\left(\mathrm{p}^{+}\right)$appear the most attractive because: 1) there is some evidence that the damage structure produced. with $16 \mathrm{MeV} \mathrm{p}^{+}$is similar to 14 . MeV neutron damage; 2) displacement rate effects can be minimized by real-time experiments while accelerated tests can be performed at 20 to $50 \mathrm{x}$ that of a fusion reactor first wal1; 3) $16 \mathrm{MeV} \mathrm{p}^{+}$can penetrate a reasonably thick $(\sim 0.25 \mathrm{~mm})$ specimen, thereby minimizing contamination from the bombarding ion and the chemical environment; 4) contamination from the accelerator is eliminated by isolating the experimental chamber from the accelerator beam line by a thin metal window.

The near term objective of this program is to correlate the microstructures and radiation hardening produced by light ions and fusion neutrons. To accomplish this objective the microstructure and yield strength change of $\mathrm{Ni}, 316 \mathrm{SS}$, and $\mathrm{Nb}$ irradiated with $16 \mathrm{MeV} \mathrm{p}^{+}$and $(\mathrm{D}, \mathrm{T})$ and $(D, B e)$ neutrons are being evaluated. The second objective of this program is to study the creep behavior of fusion candidate materials under simulated fusion reactor operating conditions.

\section{LIGHT ION/FUSION . NEUTRON CORRELATION EXPERIMENT}

The light ion/fusion neutron correlation experiment is expected to produce data which will allow a comparison between the damage efficiencies of $16 \mathrm{MeV} \mathrm{p}^{+}$and $(D, T)$ and $(D, B e)$ neutrons. Data for correlating $(D, T)$. and $(D, B e)$ neutron damage will also be produced.

\section{Light Ion Irradiations}

The light ion irradiation apparatus, helium flow system, and data readout equipment has been transported to the University of Washington Nuclear Physics Laboratory. Preirradiation set-up is in progress' with beam diagnostic tests 'planned for January 1977.. Proton irradiation 
for the $p^{+} /(D, T)$ neutron correlation experiment (see Table. 5) will begin following satisfactory beam diagnostic experiments. These include calibration of the faraday cup in a 760 torr helium atmosphere which is used for sample cooling. The experiments listed . in Table 5 are planned for completion by the end of this fiscal year.

TABLE 5. Summary of Light Ion/Fusion. Neutron Correlation Experiment

\begin{tabular}{|c|c|c|c|c|c|c|c|}
\hline Experiment & Particles & flux & $\begin{array}{c}\text { Proton } \\
\text { Fluence, } \mathrm{p}+1 \mathrm{~cm}^{2} \\
\end{array}$ & $\begin{array}{l}\text { Neutron } \\
\text { Fluence, } \mathrm{n} / \mathrm{cm}^{2}\end{array}$ & Iemp., = C & Material & $\begin{array}{l}\text { Proton } \\
\text { Beam time, hr }\end{array}$ \\
\hline$p^{+} /(n, T)$ & $\begin{array}{l}14.8-\mathrm{MeV} \\
\text { lieutrons } \\
\text { and } \\
16-\mathrm{MeV} \mathrm{p}^{+}\end{array}$ & $\left(0.2 \mathrm{a} / \mathrm{cm}^{2}-\mathrm{p}^{+}\right.$ & $\begin{array}{l}3 \times 10^{16} \\
6 \times 10^{16} \\
1 \times 10^{17}\end{array}$ & $\begin{array}{l}6 \times 10^{16} \\
1 \times 10^{17} \\
2.5 \times 10^{17} \\
5.0 \times 10^{17}\end{array}$ & $\begin{array}{ll}20, & 200 \\
20, & 200 \\
20, & 200 \\
20 & \\
20 & \end{array}$ & $\mathrm{Ni}, 316 \mathrm{sS}, \mathrm{Nb}$ & $\begin{array}{l}2 \times 8.5 \\
2 \times 17 \\
2 \times 28\end{array}$ \\
\hline $\mathrm{p}^{+} /(\mathrm{O}, \mathrm{Be})$ &  & $\begin{array}{l}10^{13} / \mathrm{cm}^{2}-\mathrm{sec} \\
12 \mathrm{a} / \mathrm{cm}^{2}-\mathrm{p}^{+}\end{array}$ & $\begin{array}{l}1 \times 10^{17} \\
5 \times 10^{17} \\
1 \times 10^{18}\end{array}$ & $\begin{array}{r}1 \times 10^{17} \\
5 \times 10^{17} \\
1 \times 10^{18}\end{array}$ & $\begin{array}{l}20-50 \\
20-50 \\
20-50\end{array}$ & $\mathrm{Ni}, 316 \mathrm{SS}, \mathrm{Nb}$ & $\begin{array}{r}2 \\
\cdot \quad 10 \\
20\end{array}$ \\
\hline High Flux & $16-\mathrm{MeV} \mathrm{D}^{+}$ & $\begin{array}{l}4 \times 10^{13} / \mathrm{cm}^{2}- \\
\mathrm{sec} \\
\left(8 . \mathrm{a} / \mathrm{cm}^{2}\right)\end{array}$ & $\begin{array}{l}5 \times 10^{17} \\
1 \times 10^{18} \\
4 \times 10^{18}\end{array}$ & $\cdots$ & $\begin{array}{l}200,500 \\
200,500 \\
200,500\end{array}$ & $\mathrm{Ni}, 316 \mathrm{SS}, \mathrm{Nb}$ & $\begin{array}{l}5.0 \\
2.0\end{array}$ \\
\hline
\end{tabular}

\section{Fusion Neutron Irradiations}

Radiation hardening data for $\mathrm{Ni}$ and $316 \mathrm{SS}$ is shown in Figure 7 where it can be seen that the nickel-wire data (PNL-nickel) is similar to the Lawrence Livermore Laboratory (LLL) copper data, : while the hardening threshold for PNL- 316 SS wire irradiated with. (D, $T$ ) neutrons at $20^{\circ} \mathrm{C}$ is above $6 \times 10^{16} \mathrm{n} / \mathrm{cm}^{2}$. Radiation hardening data for niobium is shown in . Figure 8 where it can be seen that the lowei yield point of the PNL niobium'wire data is similar to the LLL niobium data.



FIGURE 7. Comparison of $\Delta \sigma y s$ versus Neutron Fluence for Fusion and Fission NeutronIrradiated Nickel, Copper, and 316 SS 




FIGURE 8. Comparison of $\triangle \sigma y s$ for Niobium Wire (PNL) and Sheet (LLL) Irradiated with Fusion Neutrons at $20^{\circ} \mathrm{C}$

An enhanced yield point has been found for the PNL. niobium while LLL has not observed any yield point. This difference also exists for the unirradiated niobium. Irradiationenhanced yield points have been observed for fission neutron-irradiated niobium by Reed et al. (17) and Loomis and Gerber ${ }^{(18)}$ at fluences of $1-8 \times 10^{17} \mathrm{n} / \mathrm{cm}^{2}$ and $5 \times 10^{17} \mathrm{n} / \mathrm{cm}^{2}$, respectively; however, the magnitudes of $\sigma_{\text {uyp }}-\sigma_{1 y p}$ (difference between upper and lower yield points) were smaller than that observed in the present results. Further experiments are being planned to elucidate the observed enhanced yield point. The light ion/fusion neutron correlation in niobium will be based on the lower yield point because it is a better measure of bulk flow properties. The upper yield point is very sensitive to surface damage or defects which can initiate local flow and hence reduce the applied stress to cause inhomogeneous flow.

The tensile properties of the nickel, $316 \mathrm{SS}$, and niobium irradiated and tested to. date are given in Table 6.

TABLE 6. Tensile Properties $\left(20^{\circ} \mathrm{C}\right)$ of Nickel, $316 \mathrm{SS}$, and Niobium Wire $(0.18 \mathrm{~mm})$ Irradiated with $(D, T)$ Neutrons

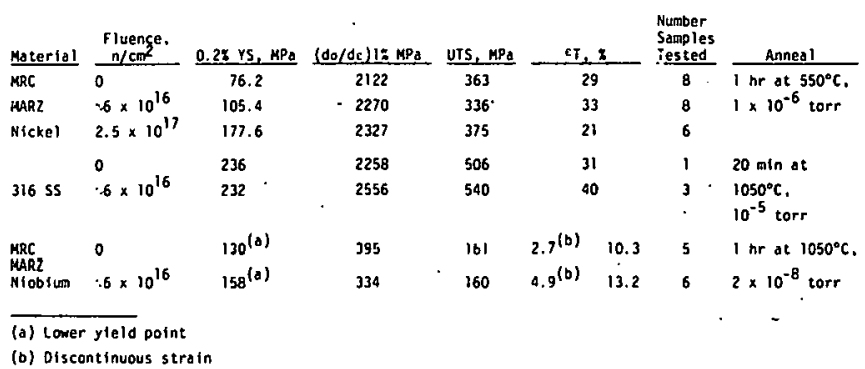




\section{FUSION REACTOR SIMULATED CREEP EXPERIMENT}

The flux, temperature, and stress of a Tokamak fusion reactor first wall will cycle with a period of a few thousand seconds. The cyclic creep behavior of materials is a problem which the fission reactor designer has not had to concern himself with while the fusion reactor designer will. Penetrating light ions are ideally suited for this type of study because of the ability to chop the ion beam and adjust the temperature and stress of the sample to simulate a fusion reactor cycle: A cyclic irradiation creep experiment is planned to follow the correlation experiment with construction of a creep module which fits the existing ion irradiation chamber. It is expected that the cyclic creep experiment will begin in FY 1978. 
Programs to identify and solve materials problems are essential to successful commercial fusion power development. The PNL materials technology program addresses areas where information will be needed for experimental and commercial reactors including the behavior of graphites and electrical insulators in fusion reactor environments. New experiments in the electrical insulator studies are examining the effects of porosity and helium buildup on the dielectric breakdown strength of insulators.

\section{EVALUATION OF CARBONS AND GRAPHITES FOR FUSION REACTOR APPLICATIONS}

W. J. Gray, W. C. Morgan, G. L. Tingey

Some fusion reactor concepts have proposed the use of a low-Z liner between the plasma and the first structural wall. A number of materials are being considered for the liner including graphite or graphite cloth. Among the more important data required before the choice of liner materials can be narrowed are: 1) radiation damage, 2) sputtering, and 3) degassing.

To provide the necessary information on graphite, the following areas are being investigated:

- Radiation Damage in Graphite Cloth - evaluation of radiation damage effects in cloths and fibers since there are no previous data for these materials above about $1 \times 10^{21}$ $\mathrm{cm}^{-2}$ EFF. (a)

- Fission-Fusion Correlation - experimental testing of the correlation between damage production rates in fission and fusion reactor spectra. This will allow more accurate projections of graphite performance in fusion reactors based on the extensive graphite data from fission reactor irradiations.

- Sputtering - measurement of neutron, ion, and chemical sputtering rates for carbon. This work is being done in conjunction with other surface science research presented in this report.

- Degassing - measurement of degassing properties of large graphite samples under conditions appropriate to fusion reactor applications.

Radiation Damage in Graphite Cloth

Disassembly of the second and third irradiation capsules, which were discharged from EBR-II in July, was delayed until September. Fluences for these irradiations were 7.3 and $10 \times 10^{21} \mathrm{~cm}^{-2} \mathrm{EFF}$, respectively; temperatures in both cases were $470^{\circ} \mathrm{C}$.

(a) A11 fluences are quoted in terms of "Equivalent Fission Fluence for Damage in Graphite."(19) 
Preliminary postirradiation examination shows that the high rate of shrinkage has continued in all four types of cloth and, at the highest fluence, is now two to three times the 28\% reported earlier at $3.5 \times 10^{21} \mathrm{~cm}^{-2}$ EFF. ${ }^{(20-22)}$ Nevertheless, three of the four types are still in good shape, typically as shown in Figure 9. Figure 10 shows the fourth type, which has deteriorated significantly.

This task, including publication of results, is expected to be completed next quarter.
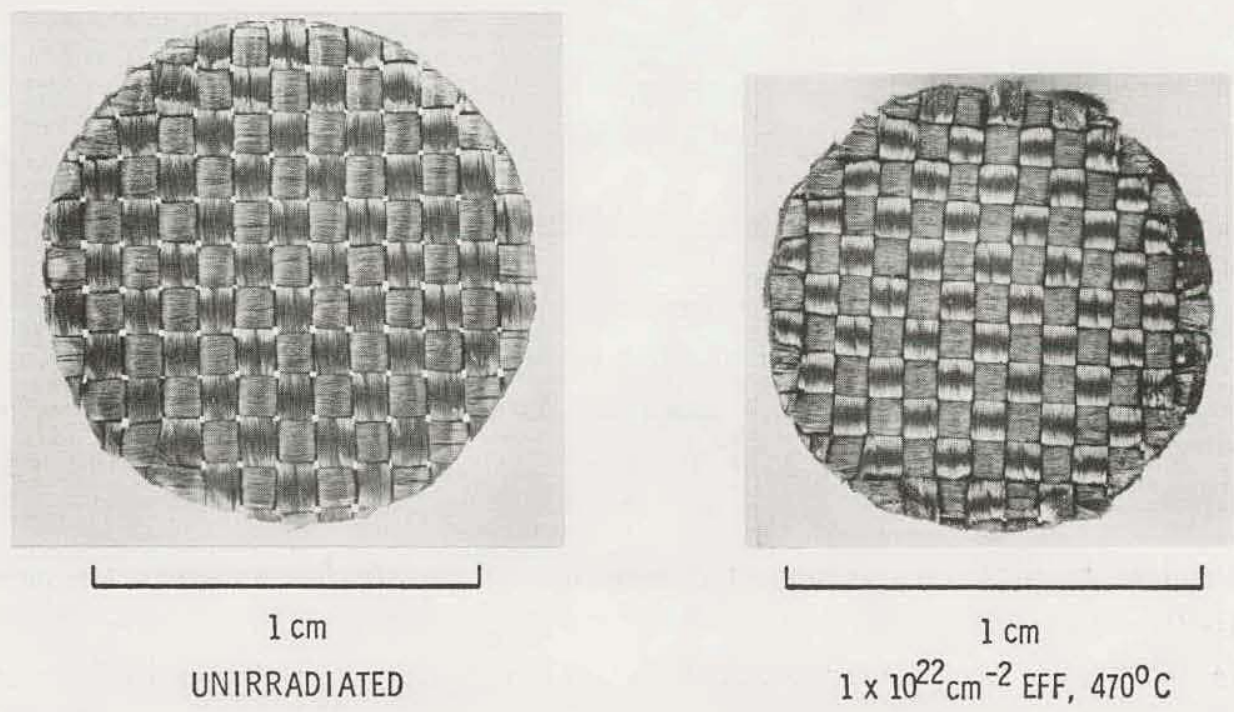

FIGURE 9. Carborundum Graphite Cloth, CSGC-2
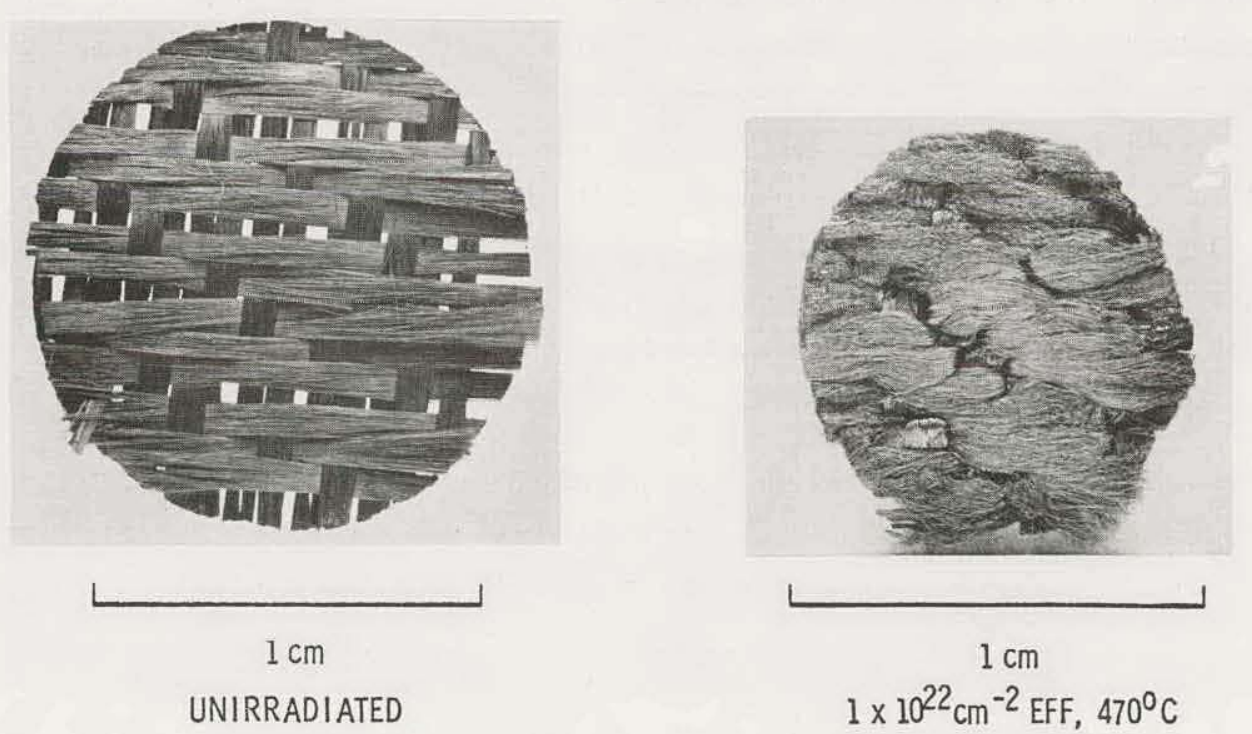

FIGURE 10. Thorne1-50 Graphite Cloth 


\section{Fission-Fusion Correlation}

Elastic modulus changes of the second set of samples, which were irradiated at the University of California-Davis ( $D, B e$ ) source with an average neutron energy of about $5 \mathrm{MeV}$, were about as expected. The third and final set of samples were irradiated in the Hanford $\mathrm{N}$-Reactor in October. Problems with sample temperature control during irradiation, however, will likely mean that this irradiation will have to be redone. This will delay task completion until next quarter.

\section{Sputtering}

Glassy carbon samples prepared in the same manner as the one labeled with ${ }^{14} \mathrm{C}$ - were found to be contaminated with sodium. Therefore, it has been assumed that the labeled sample is similarly contaminated. Heating unlabeled samples at $2400^{\circ} \mathrm{C}$ for $2 \mathrm{hr}$ totally removed the sodium as well as oxygen and other minor surface impurities. Following some additional testing of techniques with unlabeled samples, the labeled sample will be heat treated. This will be followed by two or more types of blank runs before neutron sputtering measurements are started.

\section{Degassing}

Figure " 11 is a schematic diagram of the degassing system that has been assembled." It " is based on the pressure-rise method of measuring gas content and degassing rates. After evacuating the sample chamber, the pneumatic valve is closed, and the pressure rise measurea by: the capacitance manometer is recorded. When the pressure reaches a predetermined value, the valve opens and the chamber pressure is quickly reduced to a lower predetermined value where the valve closes again. By making the pressure-rise time long compared to the pumpdown time, total: gas content as well as degassing rate can be determined. Degassing rates as low as $1 . \times 1.10^{-11}$ torr-liter/sec/gram of sample can be determined.

Equipment problems primiarly with the valve and the manometer, have been eliminated and degassing measurements are now in progress.

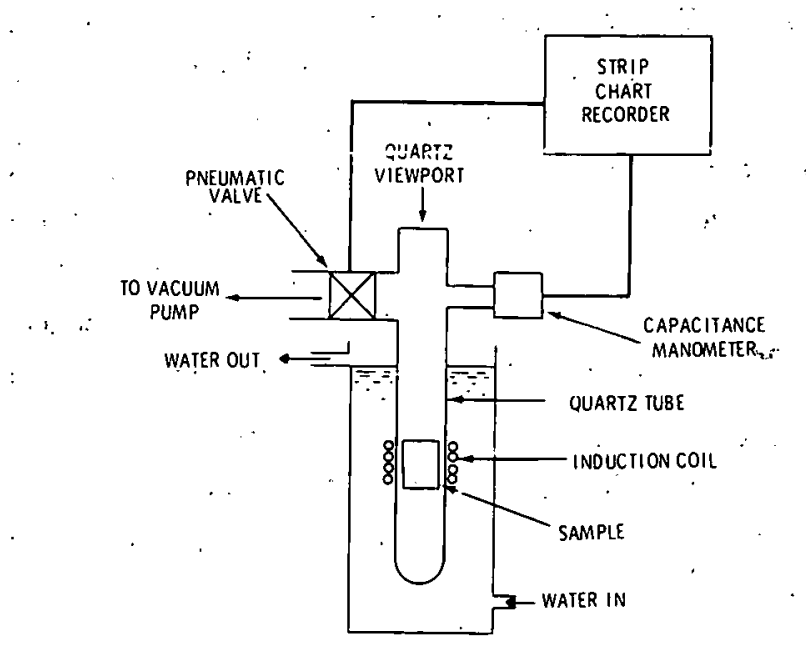

FIGURE 11. Schematic Diagram of Degassing Apparatus 


\section{ELECTRICAL INSULATORS FOR FUSION REACTOR APPLICATIONS}

J. L. Bates, J. E. Garnier

Current thermonuclear reactor technology calls for the use of electrical insulators in various critical locations in each of the Theta-Pinch, Mirror, and Tokamak designs. The insulator requirements vary within each reactor concept. The Theta-Pinch requires electrical insulators for the first wall, the inner blanket, the implosion coil, and the compression coil. Mirror reactors require inorganic electrical insulators for the baffles of the lithium coolant channels in the blanket, the high energy particle injectors, the particle collectors, and the superconducting magnet.: The Tokamak design requires electrical insulators for the li.thium coolant baffles of the blanket, neutral particle injectors, superconducting magnets, and radio frequency heaters, if used. All designs will require adequate insulation for power l.eads and instrumentation.

These various insulators will be subjected to a variety of cyclic electrical, thermal, and mechanical conditions and must function in the reactor's complex radiation environment. One of the more stringent requirements is the need for a high-temperature $\left(1100\right.$ to $\left.1500^{\circ} \mathrm{K}\right)$ insulator which is electrically, thermally, and mechanically stable to the intense neutron; particle, gamma and beta radiation, e.g., $\sim 10^{16} \mathrm{nv}$ and $210^{23} \mathrm{nvt}$. In some cases the insulator will be required to withstand very high electrical potentials ( $210 \mathrm{kV} / \mathrm{mm}$ ) under cyclic thermal and irradiation conditions at these high temperatures.

The current objective of this program is the development of a fundamental understanding of the use of acoustic emission (AE) techniques for determining prebreakdown behavior and railure mechanisms in electrical insulators. Work in this quarter has been directed towards the.establishment of experimental objectives and the initiation of experiments designed to. determine the effect of porosity and helium buildup on the dielectric breakdown strength of insulators using $A E$ techniques.

\section{EXPERIMENTAL OBJECTIVES}

Fundamental to the use of $A E$ techriques for determining prebreakdown behavior and failure mechanisms in electrical insulators is the development of an understanding of what $A E$ information can reveal. This requires an evaluation of the $A E$ breakdown technique relative to insulator structure and breakdown characteristics under high electrical stress. Studies will be conducted to determine the informational content of the recorded $A E$ data and reproducibility of results. These studies will allow definition of the usefulness of the $A E$ technique in studying effects of helium environment, electrical potential variations, temperature, irradiation, etc. on potential fusion reactor candidate insulator materials.

Since this area of research is new and no studies of this type have been made by other investigators (to the author's knowledge) the above objectives will be carried out on three selected potential fusion reactor electrical insulators. Two have been selected $\left(\alpha-\mathrm{Al}_{2} \mathrm{O}_{3}\right.$ and $\mathrm{MgAl}_{2} \mathrm{O}_{4}$ ) with a third to be chosen later. 


$$
\underline{\alpha-A l}_{2} \underline{0}_{3}
$$

Aluminum oxide is a common electrical insulator which can be supplied in high purity forms and can be fabricated by a variety of techniques. Although the radiation stability is not the best, $\alpha-\mathrm{Al}_{2} \mathrm{O}_{3}$ will be a reference oxide since other property data relative to irradiation are available and others in the fusion reactor insulator program are studying $\alpha-\mathrm{Al}_{2} \mathrm{O}_{3}$.

$$
\mathrm{MgAl}_{2} \underline{0}_{4}
$$

This oxide spinel appears to have a high potential for electrical insulator use in fusion reactor applications. The spinel is isotropic and has a relatively open lattice. structure made up of low- $Z$ elements. It can be fabricated by a variety of techniques, and the "sintering characteristics make it suitable for preparing controlled microstructures with helium-containing pores. The pure spinel (applied as a thick, dense coating to metals by plasmá spraying) has potential use as a first wall insulator or protective layer. An evalua tion of this material as a coating and bulk insulator is in progress.

\section{Helium Effects on Electrical Properties of Insulators}

Helium will be generated in electrical insulators exposed to neutron irradiation in fusion reactors. The presence of helium coupled with the other synergistic effects ' of particle and neutron radiation, such as lattice damage and impurities from transmutation, may significantly alter the electrical properties of the insulator. At the present time, there is no data on the effects of helium on the electrical resistivity or dielectric strength of insulators and little data relating to helium diffusion and solubility in insulators.

$\because$ The avatilable data do, however, suggest that helium generated in electric insulators during irradiation, either in the lattice or in pores, will potentially alter the electrical properties, in particular, the dielectric strength. Related studies with actinide oxides indicate that substantial helium still remains at $21600^{\circ} \mathrm{C}$, and below $1000^{\circ} \mathrm{C}$ helium diffusion rates are low. These studies suggest that the solubility in the electrical insulators may be low, resulting in the formation of helium-containing pores or defects. The formation of pores in itself is known to reduce the insulation capacities of ceramics. The effects of gas in the lattice of oxides on the electrical properties has also received little attention. Alpha decay in $\mathrm{PuO}_{2}$. cause a saturation of point defects, and high helium inventories result in a change in electrical properties.

One of the major problems in evaluating the helium effects on the electrical properties is the introduction of helium into the insulators: Irradiation in an environment similar to that expected in a fusion reactor is the ideal method since it combines the synergistic lattice effects resulting from irradiation. However, because it does introduce effects of lattice damage and transmutation, it would be difficult to isolate initially the potential effects resulting only from helium buildup. Cost and time suggests that other means be considered for a more rapid and controlled helium introduction.

A study is to be made on the feasibility of introducing helium into the lattice of an insulator material. A number of potential methods being considered are: 
- tritium trick

- irradiation with an alpha emitter

- doping with an alpha emitter

- ion or particle irradiation

- dissolution at high pressures and temperatures, and

- entrapment during fabrication.

Introduction of helium during fabrication by sintering will be investigated initially. Sintering at different helium pressures to high density with closed porosity will provide variable pressures of helium in the pores. Variations in the number, size, and distribution of pores can be obtained by controlling the composition and sintering conditions and by the use of pore-formers. Helium will reside predominantly in the pores.

The second method to be investigated will involve the dissolution of helium by heating the insulators in a high pressure helium environment at high temperatures. Use of single crystals and polycrystalline insulators will permit an evaluation of the effects of latticedissolved helium in contrast to that found in pores.

\section{INITIATION OF EXPERIMENTS}

To achieve the experimental objectives discussed, effort this quarter was directed towards the following:

- Experimental system setup. An experimental system is being assembled as shown in Figure 12: In a given experimental run, the following information can be obtained: a) total AE counts and energy; b) AE event energy; c) one or more individual $A E$ event signals, which can be analyzed for frequency content; and d) the number and magnitude of discharge. pulses.

- Specimen fabrication. Preparation of samples was initiated for polycrystalline $\mathrm{Al}_{2} \mathrm{O}_{3}$ and spinel with varying percentages ( 0 to $15 \%$ ) of porosity, sintered in vacuum and helium atmosphere. These samples are to be used in a detailed study of porosity and helium buildup effects on the dielectric strength of insulators.

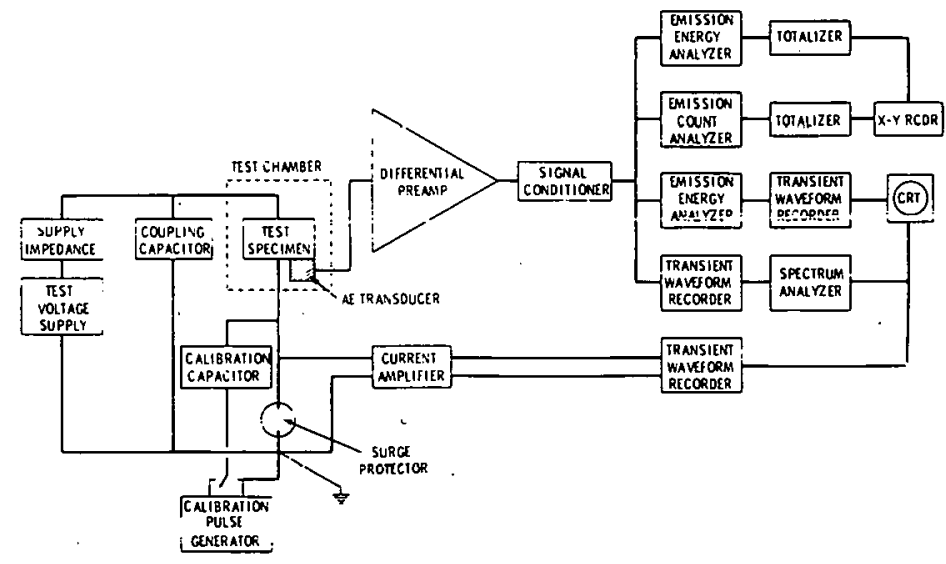

FIGURE 12. Circuit Schematic for Detection and Measurements of Acoustic Emissions and Discharge Pulses in Insulator Materials 


\section{SAFETY ANALYSIS AND ENVIRONMENTAL EFFECTS OF FUSION CONCEPTS}

In safety analysis and the environmental assessment of fusion concepts, PNL is working to assure the timely availability of information which will be required when safety analysis reports and environmental impact statements are prepared for DMFE's fusion power development program. The identification of fusion safety and environmental impacts early enough in the development program would permit maximum emphasis on research and reactor designs to minimize those impacts.

The available fusion reactor design concepts have been analyzed to determine the probable interactions with the environment and the resultant environmental effects. Although results based on current technology indicate that the fusion reactor should have a lower total environmental impact than fission power plants, adverse impacts may result from an increase in construction material usage and an increase in the radiation dose to employees. Since commercial power plants are not expected to operate for 40 to 50 years, future technical advances should lower these impacts. A document describing the analysis and eighteen supporting reference documents have been published.

PNL has begun an effort this fiscal year to define the scope of a fusion reactor safety program plan and to identify the basic technology necessary to prepare a comprehensive safety analysis report on a fusion power plant. Formulation of the plan emphasizes planning and implementation activities and the identification of safety criteria applicable to fusion reactors. This quarter, contacts were initiated with other laboratories engaged in fission safety research and an investigation was started to examine the relevance of existing fission reactor safety criteria to the fusion program. 
THIS PAGE

\section{WAS INTENTIONALLY \\ LEFT BLANK}


A correlation exists between the acceptance of a new technology and the environmental effects incurred by that technology. Therefore, the extrapolation of known data plus the generation of data from existing technologies as they could apply to fusion reactor concepts are useful in guiding the engineering of systems for future fusion reactor designs.

\section{FUSION REACTOR ENVIRONMENTAL EFFECTS}

J. R. Young

The environmental analysis for the fusion reactor development program and the supporting reference documents have been published.

The analysis was made to determine the possible environmental effects of the first commercial fusion power plants, the research necessary to assure adequate ability to describe those effects, and the power plant designs that would result in minimum adverse environmental impacts. The fusion reactor design concepts being developed were analyzed to determine the interactions with the environment and the resultant impacts. A conservative (or pessimistic) approach was used by assuming that only current technology would be used for designing the plant subsystems that control releases to the environment. Yet, the analysis still shows that fusion reactors have potential for substantially lower total environmental effects than current fossil or fission power plants or than the estimated effects of fast breeder reactors.

The environmental analysis summarizes information developed and gathered at PNL, which includes much previously unsummarized background on fusion concepts and technical analyses. The details, the unique data and individual analyses used during preparation of the larger environmental analysis, are presented in the supporting series of reference topical reports. 
The development program leading toward practical fusion power will involve the construction and operation of a number of experimental reactors. This will require an understanding of the normal and transient behavior of the reactor systems in order to assure the safety of the operating staff and the public. Potential safety concerns in such facilities and in the support activities (e.g., transportation, waste disposal, etc). need to be addressed early in the program to allow timely development of necessary data and predictive methods.

\title{
FUSION SAFETY PROGRAM PLANNING
}

\author{
H. J. Willenberg, S. H. Bush
}

PNL's fusion system safety analysis task is identifying the key needs and providing a plan for obtaining the above information. This task will also review existing and evolving safety criteria which may be applicable to fusion reactors.

\section{PLANNING AND IMPLEMENTATION}

A program plan is being developed to guide DMFE, safety-related fusion research. The pian wiii de keyed to the Fusion Power R\&D Program Projections and to the Fusion Systems Engineering Program Plan. Potential safety concerns will be identified for each major experimental program device. Information and analysis tools needed to analyze these concerns will be identified. The program plan will provide for assessment of the adequacy of existing data and analysis tools and will provide a work plan and schedule for developing additional needed information. This effort will utilize information from reactor safety studies. It will, in turn, provide schedules for development of safety analysis methods and data, safety criteria, detection and control systems, and verification experiments.

During the past quarter a full-time task leader was designated to conduct and coordinate the two safety-related activities which were initiated this quarter. A guide to the planning activity was prepared in preparation for discussions with DMFE. In addition, contacts were initiated with all laboratories engaged in fusion safety research.

\section{SAFETY CRITERIA}

The technical bases for the establishment of design criteria directed to the safety performance of fusion reactors are being identified. Available information is being reviewed for adequacy, and recommendations will be made for the provision of needed additional information. Philosophical considerations supporting specification of design criteria will be developed and documented. An examination of existing fission reactor criteria for relevance to the fusion power program was begun this quarter to initiate this component of the safety analysis task. 


\section{MANPOWER DEVELOPMENT}

To promote a better understanding of fusion technology, PNL participates in educational programs offered through the Joint Center for Graduate Study in Richland, Washington. PNL staff are currently teaching a course sequence for the three quarters of the 1976-77 academic year as a part of the University of Washington's graduate study program in Nuclear Engineering. The present quarter includes an introduction to plasma engineering and its application to controlled thermonuclear fusion. The second and third quarters will cover blanket technology and materials problems in fusion reactor conceptual designs. 


\section{THIS PAGE WAS INTENTIONALLY LEFT BLANK}


B. F. Gore, A. B. Johnson, Jr., H. B. Liemohn, F. P. Hungate

A graduate course sequence on fusion technology with a balanced emphasis of plasma and engineering aspects has been approved for addition to the Nuclear Engineering Curriculum of the University of Washington at the Joint Center for Graduate Study. (a) The Center is operated in Richland, Washington, by Oregon State University, Washington State University and the University. of Washington.

The sequence will be given routinely in three quarters starting with the 1976-77 academic year. The first quarter, which is currently being presented, covers fusion plasma engineering and includes an introduction to plasma theory and its application to controlled thermonuclear fusion. In the second quarter, main emphasis will be on blanket technology and environmental aspects. The last quarter covers candidate materials problems of principal fusion reactor conceptual designs such as first walls, coolant systems, blankets; shields, magnets, and heat exchangers. 


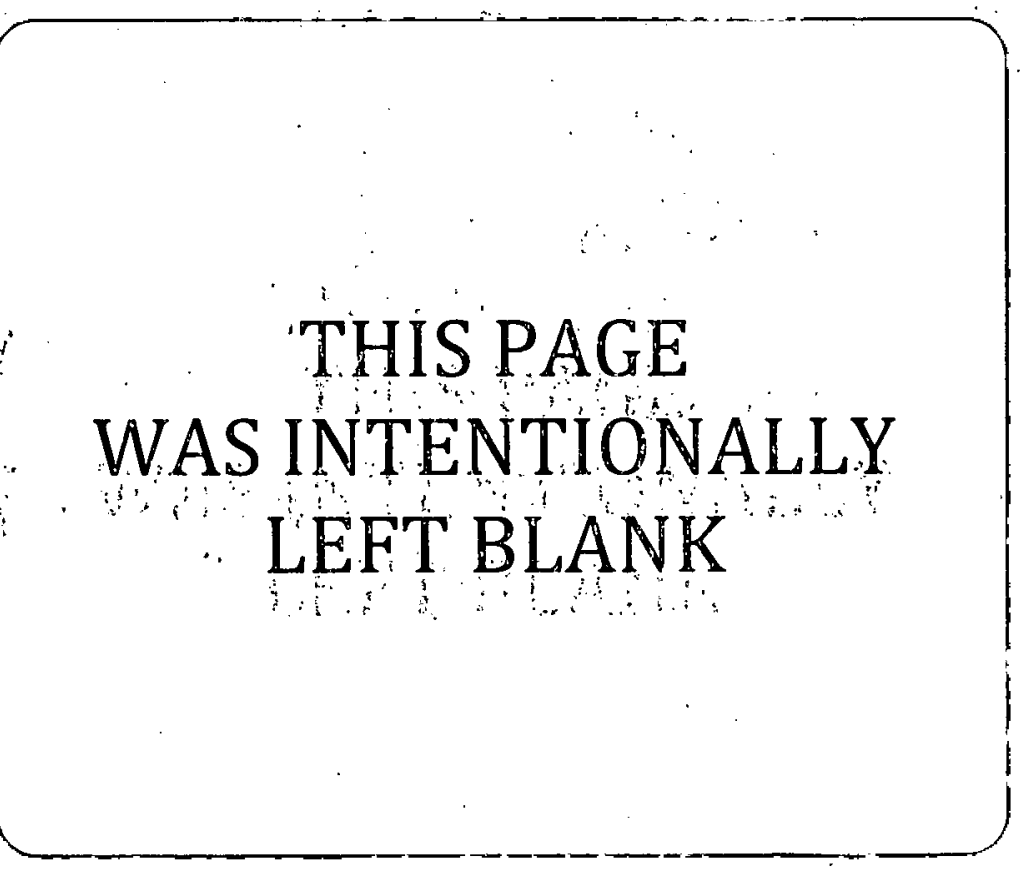

()

$v:$ 


\section{REFERENCES}

1. J. M. Dawson, H. P. Furth and F. H. Tenney, Phys. Rev. Let: : 26:1156, 1971.'

2. Tokamak Fusion Test Reactor, Volume I - Final Conceptual Design Summary. TFTR-TR-0001, Westinghouse Electric Corporation, October 1975.

3. R. W. Conn and D. L. Jassby, A Tokamak Engineering Test Reactor. OWFDM-119, Universitof Wisconsin, July 1975.

4. G. L. Kulcinski, R. W. Conn et al., TETR - A Tokamak Engineering Reactor to Qualify Materials and Blanket Components for Early DT Fusion Power Reactors. UWFDM-173, University of Wiscons, September 1976.

5. D. Bushnel1, Stress, Stability, and Vibration of Complex Branched Shells of Revolution: Analysis and User's Manual for BOSOR4. D243605, Lockheed Missile and Space Company, March 1972.

6. E. L. Wilson and R. M. Jones, Finite Element Stress Analyses of Axisymmetric Solids with Orthotropic, Temperature-Dependent Material Properties. Aerospace Corporation No. TR-0158(53816-22)-1; Air Force Report No. BSD-TR-67-228, September 1967.

7. C. L. Wheeler, C. W. Stewart, R. J. Cerna, D. S. Rowe and A. M. Sutey, Cobra-IV-1: An Interim Version of COBRA for Thermal-Hydraulic Analys is of Rod Bundle Nuclear Fuel Elements and Coves. BNWL-1962, Battelle, Pacific Northwest Laboratories, Richland, WA 99352, March 1976.

8. B. R. Leonard, Jr. and U. P. Jenquin, "The Quality of Fissile Fuel Bred in a Fusion Reactor Blanket." In Proceedings of the Second ANS Topical Meeting on the Technology of Controlled Nuclear Fusion, Volume 1. CONF-760935-Pl.

9. J. H. Vanston, Jr., and S. P. Nichols, Evaluation of the Long Term Program Plans of the U.S. Division of Controlled Thermonuclear Research. Center for Energy Studies; University of Texas, Austin, TX, February 1976.

10. The LMFBR - Its Need and Timing. ERDA-38, ERDA Division of Reactor Research and Development, Germantown; MD, May 1975. Available from National Technical Information Service; 5285 Port Royal Road, Springfield, VA 22161.

11. M. J. Makin; "The Effect of Neutron Irradiation on the Mechanical Properties of"... Copper and Nicke1." J. Inst. of Metals. 86:449, 1957-58.

12. Sh. Sh. Ubraglmov, "The Influence of Impurities on the Behavior of the Mechanical Properties of Iron and Nickel Exposed to Neutron Bombardment." Phy. Met. and Metalloy. $27(6): 130,1969$.

13. Sh. Sh. Ubraglmov, "The Effect of Plastic Deformation on the Behavior of Metals Under Neutron Bombardment." Phy. Met. and Metalloy. 22(2):176-178, 1966.

14. J. P. Andre, A. Silvent, F. Feirieux, J. Frenkel, J. Lemaire, P. Morgand and G. Sainfort, "Radiation Embrittlement of Nickel. Mechanical Properties in Extension and Creep Tests." Presented at the $10^{\mathrm{e}}$ Colloque de Metallurgie, Saclay, France, p. $199,1966$.

15. J. J. Laidler, Yielding Behavior in Neutron-Irradiated Nickel. HW-78178, p. 17, July 1963.

16. J. B. Mitche11, R. A. Konynenburg, C. J. Echer and D. M. Parkin, "DT Fusion Neutron Radiation Strengthening of Copper and Niobium." UCRL-77357 Rev. 1, presented at the International Conference on Radiation Effects and Tritium Technology for Fusion Reactors, Gatlinburg, TN, October 1-3, 1975.

17. R. E. Reed, H. D. Guberman and R. W. Armstrong, "Effect of Neutron Irradiation on the Temperature Dependence of the Flow Stress for Niobium Single Crystals." Physica Status Solidi. 37:647, 1970.

18. B. A. Loomis and S. B. Gerber, "Effect of Oxygen Impurity on Defect Agglomeration and Hardening of Neutron-Irradiated Niobium." Acta Mettalurgica. 21:165, February 1973. 
19. "ASTM Recommended Practice E525," Annual Book of ASTM Standards, Part 45. American Society for Testing Materials.

20. Pacific Northwest Report on Controlled Thermonuclear Reactor Technology, October 1975December 1975. BNWL-1939-1, Battelle, Pacific Northwest Laboratories, Richland, WA 99352, p. 39, January 1976.

21. Pacific Northwest Report on Controlied Thermonuclear Reactor Technology, April 1976 June 1976. BNWL-1939,-4, Battelle, Pacific Northwest Laboratories, Richland, WA 99352 , October 1975.

22. W. J. Gray, "Neutron Irradiation Effects on Graphite Cloth." In Proceedings of the Second ANS Topical Meeting on the Technology of Controlled Nuciear Fusion. CONF760935.

A. B. Johnson, Jr., Tritium Release from Lithium Silicate and Lithium Aluminate In-Reactor and Out-of-Reactor. BNWL-2116, Battelle, Pacific Northwest Laboratories, Richland, WA 99352, September 1976.

W. Yunker, Editor, Extraction of Tritium from Lithium Aluminate. HEDL-TME 76-81, September 1976.

A. B. Johnson, Jr., T. J. Kabele, and W. E. Gurwell, Tritium Production from Ceramic Targets: A Summary of the Hanford Coproduct Program. BNWL-2097, Battelle, Pacific Northwest Laboratories, Richland, WA 99352, August 1976. 
BNWL-1.939- 6 .

UC-20.

DISTRIBUTION

\section{OFFSITE}

A. A. Churm

ERDA Chicago Patent Group

9800 S. Cass Ave.

Argonne, IL 60439

Assistant Director for Confinement Systems

ERDA Div. of Magnetic Fusion Energy

Washington, DC 20545

Assistant Director. for Development and Technology

ERDA Div. of Magnetic Fusion. Energy

Washington, DC 20545

4 Chief, Materials and Radiation Effects Branch, D+T

ERDA Div. of Magnetic Fusion Energy.

Washington, DC' 20545

2 Chief, System Studies and Applications Branch, $D+T$

ERDA Div. of Magnetic Fusion Energy

Washington, DC 20545

Assistant Director for Plasmá Physics

ERDA: Div. of Magnetic Fusion Energy

Washingtion; DC 20545

Assistant Director for Technical Projects

ERDA Div. of Magnetic Fusion Energy

Washington, DC 20545

J. Baublitz

ERDA Div. of Magnetic Fusion Energy

Washington, DC 20545

J. W. Beal

ERDA Div. of Magnetic Fusion Energy

Washington, DC 20545

L. Bogart

ERDA Div. of Magnetic Fusion Energy

Washington, DC 20545
M. M. Cohen

ERDA Div. of Magnetic

Fusion Energy

Washington; DC 20545

E.N.C. Dalder

ERDA Div. of Magnetics

Fusion Energy

Washington, DC 20545

J. F. Decker

ERDA Div. of Magnetic

Fusion Energy

Washington, DC 20545

C. R. Finfgeld

ERDA Div. of Magnetic

Fusion Energy

Washington, DC 20545

J. N. Grace

ERDA Div. of Magnetic

Fusion Energy

Washington, DC 20545

E. E. Kintner

ERDA Div. of Magnetic

Fusion Energy

Washington, DC 20545

R. N. Kostoff

ERDA Div. of Magnetic

Fusion Energy

Washington DC 20545

J. V. Martinez

ERDA Div. of Magnetic

Fusion Energy

Washington, DC 20545

T. C. Reuther

ERDA Div. of Magnetic Fusion Energy

Washington, DC 20545

B. G. Twining

ERDA Div. of Magnetic

Fusion Energy

Washington, DC 20545

Dr. P. M. Stone

ERDA Applied Plasma

Physics Program

Washington, 'DC 20545

D. D. Mahlum

ERDA Div. of Biomedical

and Environmental

Research

Washington, DC 20545
2 Assistant Director for Materials Sciences Program

ERDA Div: of Physical Research

Washington, DC 20545

Assistant Director for Technol.ogy

ERDA Div. of Reactor

Research and

Development

Washington, DC 20545

Chief, Fuel Systems Branch

ERDA Div. of Reactor Research and Development

Washington, DC 20545

Chief, Materials and Chemistry Branch,

Office of Technology,

ERDA Div. of Reactor

Development and Demonstration

Washington, DC, 20545

ERDA Technical Information Center

2 Director, ANL CTR Program

Argonne National Laboratory

9700 S. Cass Ave.

Argonne, IL 60439

Director, Materials

Science Division

Argonne National Laboratory

9700 S: Cass Ave.

Argonne, IL 60439

D. M. 'Gruen

Argonne National

Laboratory

9700 S. Cass Avenue

Argonne, IL 60439

R. Heinrich

Argonne National

Laboratory

9700.S. Cass Ave.

Argonne, IL 60439

Distr-1 
M. S. Kaminsky

Argonne National Laboratory

9700 S. Cass Ave.

Argonne, IL 60439

V. H. Maroni

Argonne National Laboratory

9700 S. Cass Ave.

Argonne, IL 60439

F. V. Nolfi

Argonne National

Laboratory

$9700 \mathrm{~S}$ : Cass Ave.

Argonne, IL 60439

P. M. Persiani
Argonne National
Laboratory
9700 S. Cass Ave.
Argonne, IL 60439

M. Petrick

Engineering and Technology

Division

Argonne National.

Laboratory

9700. S. Cass Ave.

Argonne, IL 60439

Hianager, Materials and

Physics Technology

Atomics International

Component Engineering and

Technology Division

North American Rockwell

8900 DeSoto Ave.

Canoga Park, CA 91304

D. Kramer

Atomics International

Component Engineering and Technology Division

North American Rockwell

8900 DeSoto Ave.

Canoga Park, CA 91304

H. Farrar

Atomics International

Component Engineering and

Technology Division

North American Rockwell

8900 DeSoto Ave.

Canoga Park, CA 91304

W. E. Parkins, Manager

Atomics International

Component Engineering and

Technology Division

North American Rockwell

P.0. Box 309

Canoga Park, CA 91304
2 Chairman, Department of Applied Sciences

Brookhaven National Laboratory

Associated Universities

Upton, NY 11973

Associate Chairman for Chemistry and Materials Programs, Department of Applied Sciences

Brookhaven National Laboratory

Associated Universities

Upton, NY 11973

\section{A. N. Goland}

Brookhaven National Laboratory

Associated Universities

Upton, NY 11973

D. Gurinsky

Brookhaven National

Laboratory

ERDA Brookhaven Area

Office

Upton, NY 11973

S. Pearlstein

Brookhaven National

Laboratory

ERDÁ Brookhaven Area Office

Upton, NY 11973

J. R. Powell

Brookhaven National Laboratory

ERDA Brookhaven Area Office

Upton, NY 11973

A. J. Impink, Jr. Carnegie Melion University Pittsburgh, PA 15213

R. A. Gross

Plasma Physics Laboratory

236 SW Mudd Bldg.

Columbia University

New York, NY 10027

R. J. Tien

Plasma Physics Laboratory

Columbia University

New York, NY 10027

C. Y. Li

Cornell University

Ithaca, NY 14850

Program Manager for Fusion Power

Electric Power Research Institute

3412 Hillview Ave.

Palo A1 to, CA 94304

Distr-2
W. C. Gough

Electric Power Research Institute

3412 Hillview Ave.

Palo Alto, CA 94304

Manager, Fusion

Engineering Department

Gulf General Atomic Co.

P.0. Box 81608

San Diego, CA 92138

G. R. Hopkins

Gulf General Atomic Co.

P.0. Box 81608

San Diego, CA 92138

L. Rovner

Gulf General Atomic Co.

P.0. Box 81608

San Diego, CA 92:138

Zeinab Sabri

Nuclear Engineering Department

261 Sweeney $\mathrm{Hall}$

Iowa State University

Ames, IA : 50010

Chief; Materials and Process Department Grumman Aerospace Corp. Bethpage, NY 11714

M. D. DיAgostino

Director, Nuclear and Astrophysics. Research Grumman Aerospace Corp: Research Dept.

Bethpage, NY 11714

H. K. Forsen

Jersey Nuclear Company:

777.106 th Ave, NE

Bellevue, WA 98004

Director, CTR Division

Lawrence Livermore:

Laboratory

P.0. Box 808

Livermore, CA 94550

Director, E Division

Lawrence Livermore

Laboratory

P.0. Box 808

Livermore, CA 94550

2 Program Manager for CTR, Chemistry and Materials

Sciences Department

Lawrence Livermore

Laboratory

P.0. Box 808

Livermore, CA 94550 
R. Borg

Lawrence Livermore

Laboratory

P.0. Box 808

Livermore, CA 94550

T. K. Fowler

Lawrence Livermore Laboratory

P. 0 . Box 808

Livermore, CA 94550

A. C. Haussmann

Lawrence Livermore Laboratory

P.0. Box 808

Livermore, CA 94550

A. L. Hunt

Lawrence Livermore Laboratory

P.0. Box 808

Livermore, CA 94550

C. J. Taylor

Lawrence Livermore

Laboratory

P.0. Box 808

Livermore, CA 94550

R. VanKonynenburg

Lawrence Livermore Laboratory

P.0. Box 808

Livermore, CA 94550

L. L. Wood

Lawrence Livermore Laboratory

P.O. Box 808

Livermore, CA. 94550

Division Leader,

CTR Division

Los Alamos Scientific Laboratory

P.0. Box 1663

Los.Alamos, NM 87544

Division Leader,

CMB Division.

Los Alamos Scientific Laboratory

P.O. Box 1663

Los Alamos, NM 87544

Division Leader,

$P$ Division

Los Alamos Scientific

Laboratory

P.0. Box. 1663

Los Alamos, NM 87544

F. W. Clinard

Los Alamos Scientific Laboratory

P.0. Box 1663

Los Alamos, NM 87544
D. J. Dudziak

Los Alamos Scientific Laboratory

P.0. Box 1663

Los Alamos, NM 87544

C. R. Emigh

Los Alamos Scientific Laboratory

P.0. Box 1663

Los Alamos, NM 87544

W. Green

Los Alamos Scientific Laboratory

P.0. Box 1663

Los Alamos, NM 87544

D. B. Henderson

Los Alamos Scientific Laboratory

CTR Division

P.0. Box 1663

Los Alamos, MN 87544

L. Stewart

Los Alamos Scientific Laboratory

CTR Division

P.0. Box 1663

Los Alamos, NM 87544

Bruno Coppi

Department of Physics

Massachusetts Institute of Tecinnoiogy

Cambridge, MA 02139

0 . K. Harling

Massachusetts Institute of Technology

Cambridge, MA 02139

L. Lidsky, Department of Nuclear Engineering

Massachusetts Institute of Technology

Cambridge, MA 02139

David Rose

Massachusetts Institute of Technology

Cambridge, MA 02139

K. Russell, Department of Material's Science

Massachusetts Institute of Technology

Cambridge, MA 02139

R. E. Stickney

Mechanical Engineering

Massachusetts Institute of Technology

Cambridge, MA 02139

Distr-3
D. Krummer

McDonnel1-Douglas

Astronautics

P.0. Box 516

St. Louis, MO 63166

Manager, Technology Applications and Development

Mound Laboratory.

P.0. Box 32

Miami sburg, $\mathrm{OH} .45342$

J. J. Reinmann

NASA - Lewis Research Center

2100 Bookpark Rd.

Cleveland, $\mathrm{OH} 44135$

Director, Center for Radiation Research

National Bureau of Standards

Room C-225

Washington, DC 20234

Vincent Arp

National Bureau of Standards

Cryogenics Division

Boulder, CO 80302

T. S. Elleman

North Carolina State University

Department of Nuclear Engineering

Raleigh, NC 26707

Director, Thermonuclear Division, Bldg. 9201-2

0ak Ridge National Laboratory

P.0. Box $Y$

Oak Ridge, TN $\cdot 37830$

Director, Metals and Ceramics Division

Oak Ridge National Laboratory

P.0. Box Y

Oak Ridge, TN 37830

Program Manager, Fusion Reactor Technology Program

Bldg. 9204-1

Oak Ridge National Laboratory

P.O. Box $Y$

Oak Ridge, TN 37830

J. L. Scott, Manager. Magnetic Fusion Energy Materials

Metals and Ceramics Division.

Bldg. $4500^{\circ}$ SM, S-178

P. O. Box $X$

Oak Ridge, TN 37830 
B. R. Appleton

Oak Ridge Nationa] Laboratory

P.0. Box $Y$

Oak Ridge, TN 37830

E. E. Bloom

Oak Ridge National Laboratory

P.O. Box $Y$

Oak Ridge, TN 37830

C. R. Brinkman

Oak Ridge National Laboratory

P.0. Box $Y$

Oak Ridge, TN 37830

R..J. Colchin

Bldg. 9201-2

Oak Ridge National Laboratory

P.0. Box $Y$

Oak Ridge, TN 37830

J. H. Devan

B.ddg. 4500S

Oak Ridge National Laboratory

Oak Ridge, TN 37830

A. P. Fraas

Oak Kioge National Laboratory

P.0. Box $Y$

Oak Ridge, TN 37830

J. A. Horak

Bldg. 4500 S

Oak Ridge National Laboratory

Oak Ridge, TN 37830

W. R. Martin

Bldg. 4500 S

Oak Ridge National Laboratory

P.0. Box Y

Oak Ridge, TN 37830

J. Rand MCNally, Jr. Oak Ridge National Laboratory

P.0. Box $Y$

Oak Ridge, TN 37830

M. Roberts

Bldg. 9204-1

Oak Ridge National Laboratory

P.0. Box $Y$

Oak Ridge, TN 37830

R. Werner

Oak Ridge National

Laboratory

P. 0. Box X

Oak Ridge, TN 37830
F. W. Wiffen

Bldg. 4500 S

Oak Ridge National

Laboratory

P.O. Box $Y$

Oak Ridge, TN 37830

R. Cooper

Physics International

2700 Merced St.

San Leandro, CA 94577

R. A. Huse

Public Service Electric and Gas Co.

80 Park Place

Newark, NJ 07101

H. Perkins

Department of Chemistry

Princeton University

Princeton, NJ 06540

Director, Plasma Physics Laboratory

Princeton University

Box 451

Princeton, NJ 08540

Project Manager, TFTR

Plasma Physics Laboratory

Princeton University

Box 451

Princeton, NJ 08540

S. Cohen

Plasma Physics Laboratory

Princeton University

Box 451

Princeton, NJ 08540

R. G. Mills

Plasma Physics Laboratory Princeton University

Box 451

Princeton, NJ 08540

C. Osgood

Plasma Physics Laboratory

Princeton University

Box 451

Prinction, NJ 08540

E. C. Tanner

Plásma Physics Laboratory

Princeton University

Box 451

Princeton, NJ 08540

K. Wakefield

Plasma Physics Laboratory

Princeton University

Box 451

Princeton, NJ 08540

2 W. Bauer

Division Supervisor of

Physical Research

Sandia Laboratories

Livermore, CA 94550

Distr-4
2 S. L. Vook

Sandia Laboratories

Albuquerque, NM 87115

M. Kristiansen

Texas Tech. University

Lubbock, TX 79409

A. F. Haught

United Aircraft Research

Laboratory

United Aircraft Corp.

East Hartford, CT 06108

Head, Thermo Structural Materials Branch

U.S. Naval Research Laboratory

Metallurgy Division

Code 6390

Washington, DC 20390

F. Smidt

U.S. Naval Research Laboratory

Metallurgy Division

Code 6390

Washington, DC 20390

L. Levine

U.S. Naval Research Laboratory

Washington, DC 20390

C. Z. Serpan; Jr:

U.S. Naval Research Laboratory

Washington, DC 20390

$F$. Chen

UCLA School of Engineering and Applied Science Boelter 7731

Los Angeles, CA 90024

A. J. Lichtenberg University of California

Electronics Research Lahoratory

College of Engineering

Berkeley, CA 94720

C. D. Hendricks

University of Illinois

Nuclear Engineering

Laboratory.

Urbana, IL 61801

G. H. Miley

University of Illinois

Nuclear Engineering

Laboratory

Urbana, IL 61801

Terry Kamash

University of Michigan

Nucleár Engineering Department

Ann Arbor, MI 48105 
Dean Abrahamson

University of Minnesota

School of Public Affairs

Social Science

Building/309

Minneapolis, MN 55455

W. G. Davey

University of Texas

Department of Physics

Austin, TX 78712

E. Linn Draper, Jr. University of Texas

Department of Physics

Austin, TX 78712

W. E. Drummond

University of Texas

Department of Physics

Austin, TX 78712 .

H. G. F. Wilsdorf

University of Virginia

Department of Materials

Science

Research Labs for

Engineering Sciences

Charlottesville, VA 22901

Abraham Hertzberg

University of Washington

Aerospace Research Laboratory

316 Guggenheim

Seattle, WA 98105

A. L. Babb

University of Washington

Nuclear Engineering

Department

Seattle, WA 92105

R. Conn

University of Wisconsin

Nuclear Engineering

Department

Madison, WI 53706

G. L. Kulcinski

University of Wisconsin

Nuclear Engineering

Department

Madison, WI 53706

C. W. Maynard

University of Wisconsin

Nuclear Engineering

Department

Madison, WI 53706

D. Lichtman

Department of Physics

University of Wisconsin

Milwaukee, WI 53201
E. E. Donaldson

Washington State

University

Department of Physics

Pullman, WA 99163

Manager, Fusion Power

Systems Department

Westinghouse Electric Corp.

P.0. Box 355

Pittsburgh, PA 15230

R. Gold

Westinghouse Electric

Corp.

Research and Development Center

Beulah Road

Pittsburgh, PA 15234

J. R. Holland

Westinghouse Electric Corp.

Beulah Road

Pittsburgh, PA 15234

\section{ONSITE}

ERDA Richland Operations office

W. A. Burns

Atlantic Richfield Hanford Company

J. D. Kaser

\section{Battelle-Northwest}

D. T. Aase

G. S. Allison

T. W. Ambrose

D. G. Atteridge

D. A. Baker

M. C. Bampton

J. L. Bates

M. A. Bayne

E. R. Bradley

J. L. Brimhall

R. L. Brodzinski

R. J. Brouns

L. R. Bunnell

L. L. Burger

S. H. Bush

N. E. Carter

T. D. Chikalla

R. G. Clark

L. C. Clossey

T. L. Criswel1

S. D. Dahigren

M. .T. Dana

D. E. Deonigi

R. L. Dillon

10 D. A. Dingee

P. J. Dionne

B. H. Duane

J. W. Finnigan
J. C. Fox

J. J. Fuquay

J. E. Garnier

B. F. Gore

W. J: Gray

J. N. Hartley

A. J. Haverfield

U. P. Jenquin

A. B. Johnson, Jr.

R. H. Jones

T. J. Kabele

W. S. Kelly

H. E. Kissinger

D. A. Kottwitz

N. Laegried

B. R. Leonard, Jr.

D. L. Lesson

H. B. Liemohn

R. C. Liikala

M. A. McKinnon

R. F. Maness

R. P. Marshall

W. S. Matsumoto

R. A. McCann

E. S. Murphy

R. D: Nelson

D. R. Newman

R. E. Nightingale

D. E. Olesen

L. T. Pedersen

R. T. Perry

D. R. Pratt

L. L. Rader

L. A. Rancitelli

J. F. Remark

D. S. Renné

R. E. Rhoads

W. D. Richmond

W. F. Sandusky

E. P. Simonen

R. I. Smith

J. K. Soldat

C. W. Stewart

K. B. Stewart

R. W. Stewart

J. A. Strand

D. L. Styris

A. M. Sutey

V. L. Teofilo

G. L. Tingey

M. T. Thomas

J. K. Thompson

R. C. Thompson

L. H. Toburen

R. Wang

$R$. E. Westerman

H. J. Willenberg

L. D. Williams.

J. R. Young

M. G. Zimmerman

Technical Publication (BH)

Technical Information

Hanford Engineering

Development Labs

Manager, Materials Engineering

D. G. Doran

J. J. Holmes

J. E. Irvin

J. L. Straalsund

H. H. Yoshikawa 
